\title{
Variations in the physicochemical and optical properties of natural aerosols in Puerto Rico - Implications for climate
}

\author{
Héctor Rivera ${ }^{1}$, John A. Ogren ${ }^{2,3}$, Elisabeth Andrews ${ }^{3}$, Olga L. Mayol-Bracero ${ }^{4}$
}

$5 \quad{ }^{1}$ Department of Physics, University of Puerto Rico - Rio Piedras, San Juan, Puerto Rico

${ }^{2}$ Earth Systems Research Laboratory, National Oceanic and Atmospheric Administration, Boulder, Colorado

${ }^{3}$ Cooperative Institute for Research in Environmental Sciences, University of Colorado, Boulder, Colorado

${ }^{4}$ Department of Environmental Sciences, University of Puerto Rico - Rio Piedras, San Juan, Puerto Rico

Correspondence to: Olga L. Mayol-Bracero: (omayol@ites.upr.edu)

10 Abstract. Atmospheric aerosols stay a major cause of uncertainty in climate prediction. Hundreds of teragrams and the absorbing properties of aerosols such as African dust and volcanic ash affect radiative balance changing atmospheric temperature and thus, climate. Since 2005, we began to check the physicochemical and optical properties of aerosols at the Cape San Juan Atmospheric Observatory, Puerto Rico. Based on the Hybrid Single-Particle Lagrangian Integrated Trajectory backward trajectories and satellite imagery from the Volcanic Ash Advisory Center in Washington D.C.,

15 Moderate Resolution Imaging Spectroradiometer, and Saharan air layer images, we grouped natural aerosols in three air masses: marine, African dust and volcanic ash. A sun-sky radiometer from the NASA's AErosol RObotic NETwork assessed total aerosol optical depth and its fine fraction. A 3-wavelength nephelometer and particle soot absorption photometer assessed the scattering and absorption coefficients. Two impactors segregated the submicron $\left(D_{p}<1 \mu \mathrm{m}\right)$ particles from the total $\left(\mathrm{D}_{\mathrm{p}}<10 \mu \mathrm{m}\right)$ enabling us to calculate the sub-micron scattering and absorption fractions. The measured variables served to calculate the single scattering albedo and radiative forcing efficiency. All variables but the single scattering albedo making up the aerosol climatology for Puerto Rico had different means as function of the air mass category at $\mathrm{p}<0.05$. For the period 2005-2010, the largest means $\pm 95 \%$ confidence interval of the scattering coefficient $\left(53 \pm 4 \mathrm{Mm}^{-1}\right)$, absorption coefficient $\left(1.8 \pm 0.16 \mathrm{Mm}^{-1}\right)$, and optical depth $(0.29 \pm 0.03)$, suggested African dust is the main contributor to the columnar and surface aerosol loading in summer. About two thirds (63\%) of the absorption in African dust was due to the coarse mode and about one third due to the fine mode. In volcanic ash, fine aerosols contributed $60 \%$ of the absorption while coarse contributed $40 \%$. Overall, the coarse and fine modes accounted for $\sim 80 \%$ and $20 \%$ of the total scattering. The African dust load was 3.5 times the load of clean marine, 1.9 times greater than clean with higher sea salt content and 1.7 times greater than volcanic ash. African dust caused 50\% more cooling that volcanic ash at the top of the atmosphere and 50\% more heating than that of volcanic ash within the marine boundary layer. 
Atmos. Chem. Phys. Discuss., https://doi.org/10.5194/acp-2017-703

Atmospheric

Manuscript under review for journal Atmos. Chem. Phys.

Chemistry

Discussion started: 18 September 2017

(c) Author(s) 2017. CC BY 4.0 License.

and Physics

Discussions

(c) (i)

\section{Introduction}

Atmospheric aerosols present high uncertainty in climate prediction (Boucher et al., 2013) because of their differences in amount and size, differing also in index of refraction that depends on the chemical composition and source. Different physicochemical properties of aerosols also result in diverse optical properties influencing climate and environment in many

5 ways (Seinfeld and Pandis, 1998). Ogren (1995) pointed out that we need to evaluate the aerosols climate-forcing properties to know their spatial distribution, physical, optical, and cloud-nucleating properties, suitable radiative transfer models, and cloud physics. Anthropogenic as well as natural aerosol climate-forcing properties are important in this regard. Extensive research exists on the topic of anthropogenic aerosol climate forcing (Boucher et al., 2013); however, not so much has been done regarding natural aerosols, and even less is known about natural aerosols in the Caribbean, a region that plays a crucial

10 role in global climate by serving as an atmospheric conduit between tropical and extra-tropical regions.

The Caribbean is exposed to different type of natural aerosols such as those coming from marine sources, mineral dust from Africa and volcanic ash from the Soufriere Hills volcano in the island of Montserrat (e.g., Li-Jones and Prospero, 1998; Gioda et al., 2011; Prospero and Mayol-Bracero, 2013; Valle-Diaz et al., 2016; Wex et al., 2016). These three types of aerosols are the focus of this study.

15 For marine aerosols, oceans produce the largest primary aerosol mass emissions (Warneck 1988) and are a key source of secondary atmospheric aerosols (O’Dowd and Smith, 1993; O’Dowd et al., 2004). The mass concentration and size distribution of marine aerosols depend on the wind speed (Woodcock, 1953; Lovett, 1978; Blanchard and Woodcock, 1980). Wind speed directly correlates with the sea-salt amount, but wind speed only explains part of the variance (Quinn and Coffman, 1999; Smirnov et al., 2003). Sea-salt is non-absorbing and comprises much of the marine boundary layer (MBL)

20 aerosol mass, changing the radiative balance through scattering of visible light (Quinn et al., 1996; Winter and Chýlek, 1997). Also, sub-micron non-sea salt (nss) sulfate from biological activity scatters visible light efficiently also serving as cloud condensation nuclei (Charlson et al., 1991; Jacobson, 2001).

Turning to African dust, hundreds of teragrams reach the atmosphere every year (Huneuus et al., 2011), with large variations in emissions, in space and time (Prospero, 1999; Vinoj et al., 2004). These pace-time changing amounts result in poorly characterized African dust radiative-forcing properties (Liao and Seinfeld, 1998; Sokolik and Toon, 1999; Sokolik et al., 2001, which in turn reduces the accuracy of numerical models for predicting climate change (Houghton et al., 2001). In addition, African dust changes the radiative balance scattering and absorbing solar and terrestrial radiation. The dominant absorbing species in African dust are the iron oxides (Sokolik and Toon, 1999; Moosmüller et al., 2009).

Such as in African dust, volcanic ash changes the radiative balance by scattering and absorbing solar radiation (Bohren and

30 Huffman, 1999) because volcanic ash also holds iron oxides (Seinfeld and Pandis, 1998; Kokhanovsky, 2008). In addition, volcanic ash is hard, abrasive, and acidic (Krotkov et al., 1999; Housley et al., 2002) resulting in an aviation hazard. Evidence has shown engine failure in aircrafts flying through volcanic ash (Krotkovet al., 1999; USGS Fact Sheet, 2006). 
Atmos. Chem. Phys. Discuss., https://doi.org/10.5194/acp-2017-703

Manuscript under review for journal Atmos. Chem. Phys.

Chemistry

Discussion started: 18 September 2017

(C) Author(s) 2017. CC BY 4.0 License.

and Physics

Discussions

(c) (i)

Aerosols studies in the Caribbean goes back to the 1970's when Prospero et al. (1970) and Prospero and Carlson (1972) highlighted that synoptic outbreaks of Saharan dust occur from late spring to fall. These outbreaks extend from western Africa across the tropical Atlantic to the Caribbean. Other studies of transported African dust in the Caribbean, particularly in Puerto Rico, include those of Reid et al. (2002), Gioda et al. (2011), Fitzgerald et al. (2015), Spiegel et al. (2014); Denjean

5 et al. (2016), Raga et al. (2016) and Valle-Diaz et al. (2016). From these studies, we highlight the Puerto Rico Dust Experiment (PRIDE) (Reid et al. 2003a, b), the only study that included the radiative, microphysical, and transport properties of African dust. Reid et al. (2002) reported that during the first half of PRIDE (June 2000), dust had the highest concentrations in the marine and convective boundary layers, with lower dust concentrations above the trade inversion despite a strong Saharan Air Layer (SAL), a conceptual model by Karyampudi and Carlson (1988). PRIDE showed that

10 coarse marine aerosols produced most of the scattering and optical depth in Puerto Rico. However, the African dust coarse mode generates most of the optical depth in spring and summer (Reid et al., 2003b). Also, with single-particle analyses E. A. Reid et al. (2003) reported that elemental iron composes $\sim 2.5-3 \%$ of the total dust mass (assuming aluminium is $8 \%$ of the total mass). PRIDE excluded characterizing volcanic ash and characterizing the long-term variability of the climate-forcing properties of aerosols in Puerto Rico.

15 In this article, we characterize the climate-forcing properties of natural aerosols in Puerto Rico. We analyse aerosol data collected in Puerto Rico from 2005-2010 to: 1) classify local aerosols by source (marine, African dust and volcanic ash), 2) characterize means and variabilities in climate-forcing properties of aerosols from these three natural sources and report the monthly climatology of aerosols in Puerto Rico, 3) test the hypothesis that "means and variability of aerosols from different sources differ significantly at $\mathrm{p}<0.05$ ", and 4) determine if we can distinguish the kind of aerosol only knowing their mean

20 and variability in the climate-forcing properties.

\section{Experimental}

The sampling site was the Cape San Juan Atmospheric Observatory, at the natural reserve of Cabezas de San Juan, Puerto Rico (CPR), with coordinates $\left(18^{\circ} 22.85^{\prime} \mathrm{N}, 65^{\circ} 37.07^{\prime} \mathrm{W}\right)$, managed by the Atmospheric Chemistry and Aerosols Research group at the University of Puerto Rico - Rio Piedras Campus, and supported by the Aerosol Group of the Global Monitoring Division at the National Oceanic and Atmospheric Administration's Earth System Research Laboratory (NOAA/ESRL). CPR is a coastal site influenced by the trade winds most of the year where the absence of large land areas upwind reduces anthropogenic aerosols. African dust disturbs the marine environment of CPR from late spring to mid fall with stronger events in late spring and summer. Emissions from the Soufriere Hills volcano in Montserrat also disturb CPR if the low-level winds are southeast because Puerto Rico is about $400 \mathrm{~km}$ northwest of Montserrat. 
Atmos. Chem. Phys. Discuss., https://doi.org/10.5194/acp-2017-703

Manuscript under review for journal Atmos. Chem. Phys.

Discussion started: 18 September 2017

(c) Author(s) 2017. CC BY 4.0 License.

(c) (i)
Atmospheric

Chemistry

and Physics

Discussions

\subsection{In-situ aerosol measurements}

The aerosol measurements at CPR follow the NOAA Earth System Research Laboratory (Figure 1) network sampling protocols (http://esrl.noaa.gov/gmd/aero/net/), consistent with the guidelines of the World Meteorological Organization (WMO, 2016) aerosol measurements in the Global Atmosphere Watch. Delene and Ogren (2002) describe the aerosol

5 monitoring. In Figure 1, a TSI model 3563 integrating nephelometer measures the aerosol scattering ( $\left.\sigma_{\mathrm{sp}}\right)$ and backscattering ( $\left.\sigma_{\text {bsp }}\right)$ coefficients at 450, 550 and $700 \mathrm{~nm}$. In addition, a Radiance Research Particle Soot Absorption Photometer (PSAP) measures the aerosol absorption coefficient $\left(\sigma_{\mathrm{ap}}\right)$ at 467, 530, and $660 \mathrm{~nm}$. The absorption at $530 \mathrm{~nm}$ was adjusted by $\log -\log$ interpolation to $550 \mathrm{~nm}$ to yield $\sigma_{\mathrm{ap}}$ and $\sigma_{\mathrm{sp}}$ at the same wavelength $(550 \mathrm{~nm})$. Upstream of the nephelometer and PSAP a heater warms the aerosol sample to reduce the relative humidity to values around $40 \%$. Two switched impactors segregate

10 the aerosols in sub-micron $\left(D_{p}<1 \mu \mathrm{m}\right)$ and total $\left(D_{p}<10 \mu \mathrm{m}\right)$ fractions to compare the fine with the total aerosol contributions.

\subsubsection{Description of in-situ variables}

Variables $\sigma_{\mathrm{sp}}, \sigma_{\mathrm{ap}}$ and extinction coefficient $\left(\sigma_{\mathrm{ext}}\right)$ are extensive parameters (Ogren, 1995). Extensive parameters depend on aerosol amount and are additive. We report $\sigma_{\mathrm{sp}}$ and $\sigma_{\mathrm{ap}}$ in $\mathrm{Mm}^{-1}\left(1 \mathrm{Mm}^{-1}=10^{-6} \mathrm{~m}^{-1}\right)$.

15 Calculating the sub-micron scattering $\left(\mathrm{R}_{\mathrm{sp}}\right)$ and absorption $\left(\mathrm{R}_{\mathrm{ap}}\right)$ fractions allowed us to test the contribution of the submicron mode to the total scattering or absorption. The $R_{s p}$ and $R_{a p}$ are intensive (i.e., independent of aerosol amount) and non-dimensional parameters associated with the scattering or absorbing particles size distributions (Ogren 1995). Intensive and extensive parameters are variables in chemical transport and radiative transfer models. We calculated $R_{s p}$ and $R_{a p}$ with Eqns. (1) and (2) from Delene and Ogren (2002).

20

$$
\begin{aligned}
& \mathrm{R}_{\mathrm{sp}}\left(\mathrm{D}_{\mathrm{p}}\right)=\frac{\sigma_{\mathrm{sp}}\left(\mathrm{D}_{\mathrm{p}}<1 \mu \mathrm{m}\right)}{\sigma_{\mathrm{sp}}\left(\mathrm{D}_{\mathrm{p}}<10 \mu \mathrm{m}\right)} \\
& \mathrm{R}_{\mathrm{ap}}\left(\mathrm{D}_{\mathrm{p}}\right)=\frac{\sigma_{\mathrm{ap}}\left(\mathrm{D}_{\mathrm{p}}<1 \mu \mathrm{m}\right)}{\sigma_{\mathrm{ap}}\left(\mathrm{D}_{\mathrm{p}}<10 \mu \mathrm{m}\right)}
\end{aligned}
$$

25 The scattering Ångström exponent (å) is an intensive parameter describing the spectral dependence of the scattering (Eqn. (3))

$\sigma_{\mathrm{sp}}=\mathrm{B} \lambda^{-\mathrm{a}}$ 
Atmos. Chem. Phys. Discuss., https://doi.org/10.5194/acp-2017-703

Manuscript under review for journal Atmos. Chem. Phys.

Discussion started: 18 September 2017

(c) Author(s) 2017. CC BY 4.0 License.

(c) (i)
Atmospheric

Chemistry

and Physics

Discussions

with $\sigma_{\text {sp }}$ the scattering coefficient, B the scattering coefficient at a wavelength $\lambda$ of one $\mu \mathrm{m}$, and å the scattering Ångström exponent. We calculated the scattering Ångström exponent with Eqn. (4).

$$
\mathrm{a}=-\frac{\log \left(\sigma_{\mathrm{sp}}^{550} / \sigma_{\mathrm{sp}}^{700}\right)}{\log \left(\frac{550}{700}\right)}
$$

In Eqn. (4), $\sigma_{s p}^{550}$ and $\sigma_{s p}^{700}$ are the scattering coefficients at 550 and $700 \mathrm{~nm}$. The scattering Ångström exponent qualitatively measures the sizes of scattering particles. The greater the Ångström exponent the smaller is the size of the scattering particles.

In addition, we calculated the single scattering albedo $\left(\omega_{0}\right)$, a non-dimensional intensive quantity, to estimate the contribution of scattering to extinction with Eqn. (5).

$$
\omega_{0}=\frac{\sigma_{s p}}{\sigma_{a p}+\sigma_{s p}}
$$

The $\omega_{0}$ is part of the radiative forcing per unit of optical depth $\left(\Delta \mathrm{RF} / \delta_{\mathrm{ae}}\right)$ at the top of the atmosphere, called radiative forcing efficiency after Sheridan and Ogren (1999). The $\Delta \mathrm{RF} / \delta_{\mathrm{ae}}$ depends on the aerosol size through the upscatter fraction $\beta$, the

15 scattering and absorption through $\omega_{0}$, and on seven geophysical quantities. We calculated the upscatter fraction with Eqn. $\beta=$ $0.0817+1.8495 \mathrm{~b}-2.9682 \mathrm{~b}^{2}$, where the backscatter fraction $\mathrm{b}$ was calculated with Eqn. $\mathrm{b}=\sigma_{\mathrm{bsp}} / \sigma_{\mathrm{sp}}$. This parameterization, presented by Sheridan and Ogren (1999), omits the dependence of $\beta$ with the zenith angle. The radiative forcing efficiency for daytime-average was calculated with Eqn. (6).

$20 \frac{\Delta R F}{\delta_{a e}}=-D S_{0} T_{a t}^{2}\left(1-A_{c}\right) \omega_{0} \beta\left\{\left(1-R_{s}\right)^{2}-\left(2 \frac{R_{S}}{\beta}\left[\left(\frac{1}{\omega_{0}}\right)-1\right]\right)\right\}$

Eqn. (6) assumes a constant geographical surface reflectance $\left(R_{s}\right)$ and atmospheric transmission $\left(T_{\mathrm{at}}\right)$, with the values for the fractional day length $(\mathrm{D})=0.5$, solar constant $\left(S_{\mathrm{o}}\right)=1370 \mathrm{~W} \mathrm{~m}^{2}, T_{\text {at }}=0.76$, fractional cloud amount $\left(A_{c}\right)=0.6$, and $R_{s}=0.15$ proposed by Haywood and Shine (1995). The aerosol measurements are at $550 \mathrm{~nm}$ (Delene and Ogren, 2002).

\subsection{Ground-based remote aerosol measurements}

A CIMEL Electronique 318A spectral radiometer, part of NASA's AErosol RObotic NETwork (AERONET), assessed the total aerosol optical depth $\left(\delta_{\mathrm{ae}}\right)$ and aerosol optical depth fine fraction $\left(\delta_{\mathrm{ae}} \mathrm{FF}\right)$. Holben et al. (1998) detail how to find $\delta_{\mathrm{ae}}$. The total aerosol optical depth $\delta_{\mathrm{ae}}$ is the integral in the vertical of $\sigma_{\mathrm{ext}, \lambda}, \delta_{\mathrm{ae}}$ is a non-dimensional extensive parameter. AERONET finds the fine fraction with the Spectral Deconvolution Algorithm (SDA; O'Neill, 2001, 2003). Also, AERONET uses the number size distributions to derive the volume size distribution through an inversion algorithm by Dubovik and King (2000). 
Atmos. Chem. Phys. Discuss., https://doi.org/10.5194/acp-2017-703

Manuscript under review for journal Atmos. Chem. Phys.

Chemistry

Discussion started: 18 September 2017

(C) Author(s) 2017. CC BY 4.0 License.

and Physics

Discussions

(c) $($ P)

We present volume size distributions to support other results. AERONET columnar measures are at $500 \mathrm{~nm}$ (green) to compare with the $550 \mathrm{~nm}$ (also green) at the surface.

\subsection{Models and satellite data}

We used the Hybrid Single Particle Lagrangian Integrated Trajectory (HYSPLIT) Model (Draxler and Hess, 1998; Draxler

and Rolph, 2013) to estimate air mass trajectories from the sources to CPR. Moderate Resolution Imaging Spectroradiometer (MODIS) images served to sense possible African dust, volcanic emissions, or clean marine. SAL images proved useful to sense possible African dust over CPR. We used SAL images from http://tropic.ssec.wisc.edu/archive/. Images from the Volcanic Ash Advisory Center (VAAC) in Washington D.C. also served to sense volcanic ash if MODIS images were unavailable. VAAC obtains data from three Geostationary Operational Environmental Satellite (GOES) satellites (GOES-11, GOES-12, and GOES-13) covering from the central Pacific to the eastern Atlantic.

\subsection{Data processing and quality control}

Nephelometer data were corrected for instrumental non-idealities, such as truncation error, after Anderson and Ogren (1998). The method corrects scattering measurements over integration angles of $\sim 7^{\circ}-170^{\circ}$ and $\sim 90^{\circ}-170^{\circ}$ to the full $0^{\circ}-180^{\circ}$ and $90^{\circ}-180^{\circ}$ ranges, based on the measured scattering Ångström exponent (̊̊). The scattering Ångström exponent qualitatively

15 describes the scattering particles sizes (Anderson and Ogren, 1998). Concerning particles larger than the scattered light wavelength, the truncation error is greater than that of other systematic errors and can become twice larger. Uncertainties also arise because the nephelometer is calibrated with a gas (Carbon dioxide), which scatters in a Rayleigh regime, and aerosols scatter in the Mie regime. Scattering from gas molecules (Rayleigh scattering) is subtracted from the total scattering to find scattering by aerosol particles. Corrections to PSAP data were based on Bond et al. (1999), reporting a 20-30\%

20 overall overestimation of absorption measured by the PSAP due to scattering aerosols on the filter before applying correction. Ogren (2010) extended the Bond et al. (1999) corrections to apply to measurements of a 3-wavelength PSAP.

We manually edited one-minute data from the nephelometer and PSAP to invalidate bad data associated with equipment maintenance and malfunction. The edited 1-minute data files were averaged to create the daily averaged data files. In addition, we checked for consistency of data and impossible values such as $R_{s p}, \omega_{o}>1$. We kept these data in the database but omitted them from the plots. Absorption data and the variables depending on absorption (i.e., $\omega_{0}$ and $\Delta R F / \delta_{\mathrm{ae}}$ ) began in 2006 . We used AERONET level 2 data, screened for clouds and quality assured by NASA (Holben et al., 2006).

\section{Results and Discussion}

First, we describe how we classified the air masses and a few exceptions to the method. Second, we analyse means and variations in climate-forcing properties, discussing how these means and variations support or contradict our hypothesis. 
Atmos. Chem. Phys. Discuss., https://doi.org/10.5194/acp-2017-703

Manuscript under review for journal Atmos. Chem. Phys.

Discussion started: 18 September 2017

(c) Author(s) 2017. CC BY 4.0 License.

Finally, we discuss the monthly variation of the climate-forcing properties. We focused on a comparison of volcanic ash to other air masses because volcanic ash is a hazard to aviation and our results might serve to detect volcanic ash. We also highlight differences between volcanic ash and African dust because, to the naked eye, these aerosols might look similar, but are different.

\section{3.1 Aerosol Classification by Source}

We present our criteria to classify air masses in Table 1. The method, however, produces uncertainty because we classified average air masses daily but MODIS images are unavailable at night.

\subsubsection{Clean marine aerosols}

Clean marine (CM) aerosols form in the ocean with imperceptible influence from other air masses, natural or anthropogenic,

10 with $\sigma_{\mathrm{sp}} \leq 20 \mathrm{Mm}^{-1}, \sigma_{\mathrm{ap}} \leq 0.6 \mathrm{Mm}^{-1}, \delta_{\mathrm{ae}} \leq 0.1$, and trajectories only over the ocean. Trajectories were at 06 and $12 \mathrm{Z}$ for 100 , 500 and $1000 \mathrm{~m}$ above sea level. The clean marine with greater sea salt content (CMS) aerosol met the criteria in CM but, $\sigma_{\mathrm{sp}}$ $>20 \mathrm{Mm}^{-1}$ and $\delta_{\mathrm{ae}}>0.1$. This definition was based on reports by Kleefeld et al. (2002) on the dependence $\sigma_{\mathrm{sp}}$ with wind speed (square of the speed) and Lewis and Schwartz (2004) that wind speed is a main driver producing natural marine aerosols. VAAC and MODIS images served to verify non-marine aerosols.

\section{$15 \quad$ 3.1.2 African dust}

To find African dust (AD), we searched MODIS images for dust clouds leaving western Africa in spring, summer, and fall (see Table 1). If we saw elevated aerosol loads in Puerto Rico about 6-7 days later, we classified the air mass as African dust. An example is the dust cloud over Dakar in May 28, 2010 (Figure 2a), seen over Puerto Rico on June 3, 2010 (Figure 2b). $\mathrm{AD}$ in Figures $2 \mathrm{a}$ and $2 \mathrm{~b}$ was, as in other $\mathrm{AD}$ events, light brown covering large areas of the Caribbean and Atlantic. $\mathrm{AD}$

20 trajectories were from the east, east-southeast, or southeast. Strong AD episodes such as the event on June 3, 2010 were easily identifiable with MODIS.

\subsubsection{Volcanic ash}

We classified an air mass as volcanic ash (VA) if the Soufriere Hills' volcano emitted simultaneously with southeast lowlevel winds, trajectories, and cloud streaks orientation (see Table 1). Figure 3 shows an example during January 9, 2007. We

25 also used cloud streak orientations to estimate the prevailing wind direction because cloud streaks orient parallel to the prevailing winds. 
Atmos. Chem. Phys. Discuss., https://doi.org/10.5194/acp-2017-703

Atmospheric

Manuscript under review for journal Atmos. Chem. Phys.

Chemistry

Discussion started: 18 September 2017

(C) Author(s) 2017. CC BY 4.0 License.

and Physics

Discussions

(c) $($ P)

\subsubsection{North America and South America air masses}

Air masses from North America occurred more in winter or fall, associated with the cold fronts general circulation, as HYSPLIT trajectories suggested. We linked the South America air mass with the broad circulation of cyclones north of Puerto Rico promoting southerly low-level winds. We excluded the North and South America air masses because they only occurred a few times.

\subsubsection{Exceptions to the classification method}

The classification scheme (Table 1) is objective, and a subjective assessment of the classification results led to changes in the assigned classes a few times. As follows, volcanic ash reaches CPR if the Soufriere Hills' volcano emits simultaneously with southeast low-level winds, cloud streaks and trajectories. One exception is when the ash is already in the Atlantic northeast of Puerto Rico (Figure 4). In this instance, winds shifting to the northeast can bring volcanic ash to Puerto Rico.

Also, we used SAL images cautiously because of times that MODIS suggested heavy dust (Figure 5a) over Puerto Rico but SAL images suggested no dust (Figure 5b). Also, Figures 5a and 5b show cloud streaks oriented from northeast to southwest instead of southeast to northwest but we classified the air mass as $\mathrm{AD}$ because $\mathrm{AD}$ was clear. This example suggests that African dust transport from the Atlantic to CPR.

\section{$15 \quad 3.2$ Extensi ve variables by air mass}

\subsubsection{Scattering $\left(\sigma_{s p}\right)$ and absorption $\left(\sigma_{a p}\right)$ coefficients}

Figure 6 shows the $\sigma_{\mathrm{sp}}$ frequency distributions for $\mathrm{AD}$ and VA. We verified that these distributions are log-normal by taking the logarithm of the data and applying a normality test. A greater number of values are between $\sim 10$ and $100 \mathrm{Mm}^{-1}$ with a smaller number of extreme values and empty spaces between them in $\mathrm{AD}$.

20 Statistically, the empty spaces in the $\mathrm{AD}$ frequency distribution suggest that the more extreme $\mathrm{AD}$ e vents might have distinct causes. But studying the potential causes was out of our scope. Alternatively, the extreme events might all have the same cause but the study period was insufficient to fill in the gaps. Note in Figure 6 that in $\mathrm{AD}$, $\sigma_{\mathrm{sp}}$ had a greater range $\left(230 \mathrm{Mm}^{-1}\right)$ in strength compared with that of VA $\left(75 \mathrm{Mm}^{-1}\right)$.

Table 2 summarizes aerosol data collected from 2005-2010. Comparing the aerosol loads among air masses within the MBL,

25 we found that mean $\sigma_{\mathrm{sp}}$ in $\mathrm{AD}$ was significantly greater than mean $\sigma_{\mathrm{sp}}$ otherwise (3.5 times greater than $\mathrm{CM}, 1.9$ times greater than CMS with greater sea salt content and 1.7 times greater than VA). Hence, mean atmospheric aerosol load increased, on average, 3.5 times near the surface and the $\mathrm{MBL}$ if $\mathrm{AD}$ replaced $\mathrm{CM}$. Also, the greater number of $\mathrm{AD}$ events ranged from 30 to $35 \mathrm{Mm}^{-1}$ and in VA ranged from 15 to $20 \mathrm{Mm}^{-1}$. Mean $\sigma_{\mathrm{sp}}$ in $\mathrm{AD}$ and VA differed by $23 \mathrm{Mm}^{-1}$ with a $95 \%$ confidence interval (CI) from 16.8 to $27.8 \mathrm{Mm}^{-1}$. These results support our hypothesis with respect to aerosol loads. 
Atmos. Chem. Phys. Discuss., https://doi.org/10.5194/acp-2017-703

Manuscript under review for journal Atmos. Chem. Phys.

Chemistry

Discussion started: 18 September 2017

(c) Author(s) 2017. CC BY 4.0 License.

and Physics

Discussions

(c) (i)

Concerning columnar data, the volume size distribution for the VA e vent shown in Figure 7a shows fine aerosols (i.e. not the marine aerosols) dominating the volume (Figure (7b). In contrast, for the VA event shown in Figure 7c, the volume size distribution (Figure 7d) shows coarse aerosols (such as the marine aerosols) dominating the volume. These results imply that VA events are variable enough that sometimes VA dominates the column loading and sometimes sea-salt dominates,

5 implying that two distinct aerosols are present in the VA air mass. However, the optical data in Table 2 shows that VA dominates the light scattering during VA events because the light scattering efficiency of coarse-mode particles is much lower than that of fine-mode particles. Therefore, in some VA events, sea-salt might dominate the column mass loading, but VA will dominate the scattering and optical depth.

Turning back to surface data, the ratio of the mean absorption coefficients $\left(\sigma_{a p}\right)$ between AD and VA suggests that AD

10 absorbs $50 \%$ more sunlight than what VA absorbs. To calculate the local heating rate after the absorption by VA or AD we combined the Beer's Lambert law for the absorption rate, $\frac{\mathrm{dF}}{\mathrm{dz}}=\frac{\sigma_{\mathrm{ap}}}{\mu} \mathrm{F}$ with the equation for the local heating rate, $\frac{\mathrm{dT}}{\mathrm{dt}}=$

$\frac{1}{\mathrm{C}_{\mathrm{p}} \rho} \frac{\mathrm{dF}}{\mathrm{dz}}$ and obtained, $\frac{\mathrm{dT}}{\mathrm{dt}}=\frac{\sigma_{\mathrm{ap}}}{\mu \mathrm{C}_{\mathrm{p}} \rho} \mathrm{F}$, where $F$ is the flux density at altitude $\mathrm{z} ; \frac{\mathrm{dF}}{\mathrm{dz}}$ is the absorption rate; $\mu$ is the cosine of the zenith angle; $\sigma_{\mathrm{ap}}$ is the absorption coefficient; $\mathrm{C}_{\mathrm{p}} \rho$ is the heat capacity of air $\left(1 \mathrm{~kJ} \mathrm{~K}^{-1} \mathrm{~kg}^{-1}\right)$ times $\rho$, the density of air; and $\mathrm{dT} / \mathrm{dt}$ is the local heating rate. The equation for the heating rate is directly proportional to the absorption coefficient. If we

15 substitute the absorption coefficient for $\mathrm{AD}$ and $\mathrm{VA}$ in the last equation, we get that the change in temperature in $\mathrm{AD}$ is $50 \%$ greater than the change in temperature of VA. This result only considers the change in temperature due to absorption but omits the effect on temperature due to radiation cooling. An implication of this result is the need to measure the absorption coefficient accurately. To keep or improve this accuracy needs that we continue actual efforts to measure absorption. In the next section, we analyze columnar optical depth, contrasting, or comparing it with the surface scattering.

\section{3.2.2 Col umnar Aerosol Optical Depth}

Similar to the surface mean $\left(\sigma_{\mathrm{sp}}\right)$ the columnar mean $\left(\delta_{\mathrm{ae}}\right)$ in $\mathrm{AD}$ was greater than that of other air masses. Namely, mean $\delta_{\mathrm{ae}}$ in $\mathrm{AD}$ was 5 times greater than that of $\mathrm{CM}$ and 3.5 times greater than that of $\mathrm{CMS}$. In contrast, $\sigma_{\mathrm{sp}}$ in $\mathrm{AD}$ was 3.5 times greater than that of CM and 1.9 times greater than that of CMS. The different ratios imply a greater AD fraction transported above, than within the MBL. For VA, mean $\sigma_{\mathrm{sp}}$ was 1.1 times greater than that of CMS and the columnar mean $\delta_{\mathrm{ae}}$ in VA was 1.6 times greater than that of CMS. Therefore, VA enhanced the optical depth more than the surface scattering if VA superimposed a CMS air mass. Also, VA enhanced both the scattering and the optical depth twice. Furthermore, mean $\sigma_{\text {sp }}$ in $\mathrm{AD}$ was 1.7 times greater than that of VA and mean $\delta_{\mathrm{ae}}$ was 2.1 times greater. Therefore, within the MBL, AD increased the scattering $70 \%$ more than that of VA and doubled the columnar optical depth produced by VA. In summary, we found that different air masses affect climate differently because their distinct amounts produce different scattering or extinction. 
Atmos. Chem. Phys. Discuss., https://doi.org/10.5194/acp-2017-703

Manuscript under review for journal Atmos. Chem. Phys.

Chemistry

Discussion started: 18 September 2017

(c) Author(s) 2017. CC BY 4.0 License.

and Physics

Discussions

(c) (i)

\subsection{Intensi ve variables by air mass}

\subsubsection{Columnar Aerosol Optical Depth Fine Fraction $\left(\delta_{\mathrm{ae}} \mathrm{FF}\right)$}

Concerning particle sizes causing extinction in the atmospheric column, an overall mean $\delta_{\mathrm{ae}} \mathrm{FF}$ of 0.27 implies that, on average, coarse particles caused three-fourths of the aerosol extinction. In addition, mean $\delta_{\mathrm{ae}} \mathrm{FF}$ among air masses was

5 significantly different, except between CM and CMS. This result suggests that in Puerto Rico, different air masses have significantly different columnar size distributions. For instance, the mean $\delta_{\mathrm{ae}} \mathrm{FF}$ in VA was 0.09 more than mean $\delta_{\mathrm{ae}} \mathrm{FF}$ in $\mathrm{AD}$ with a 95\% CI from 0.04-0.14. Hence, at $\mathrm{p}<0.05$, columnar VA aerosols were on average, significantly smaller than columnar $\mathrm{AD}$ and columnar marine aerosols. In other words, we are more than $95 \%$ certain that columnar VA aerosols are smaller than columnar $\mathrm{AD}$ or marine aerosols. The mean $\delta_{\mathrm{ae}} \mathrm{FF}$ in marine and $\mathrm{AD}$ aerosols differed significantly by $\sim 0.03$.

10 These results support our hypothesis concerning aerosol sizes. Users of these data should decide if these differences, although significant, are meaningful to them. Our results, in agreement with Reid et al. (2003b), show that coarse aerosols dominate the extinction in Puerto Rico.

\subsubsection{Scattering $\left(\boldsymbol{R}_{s p}\right)$ and Absorption $\left(\boldsymbol{R}_{a p}\right)$ Fractions}

Concerning the sizes of the scattering particles, mean sub-micron scattering fractions, $\mathrm{R}_{\mathrm{sp}}$, were on average low (Table 2),

15 with a mean of 0.2 . Hence, coarse aerosols produced $80 \%$ of the scattering within the MBL. In addition, mean $\mathrm{R}_{\mathrm{sp}}$ in VA was significantly greater than mean $\mathrm{R}_{\mathrm{sp}}$ in $\mathrm{AD}$. Even tough they only differed by 0.03 with a $95 \% \mathrm{CI}$ from 0.01 to 0.05 , the result means that we are more than $95 \%$ certain that, within the MBL, volcanic ash has a smaller fraction of coarse scattering particles than what $\mathrm{AD}$ and marine aerosols have. The lowest mean $\mathrm{R}_{\mathrm{sp}}$ in marine aerosols implies that marine aerosols have the largest fraction (> 85\%) of coarse aerosols. Therefore, the scattering particles sizes among natural aerosols in Puerto Rico

20 were significantly different, supporting our hypothesis.

Turning to the sizes of the absorbing particles, an overall mean sub-micron absorption fraction, $\mathrm{R}_{\mathrm{ap}}$, of 0.5 shows that on average, coarse and fine absorbing aerosols within the MBL in Puerto Rico have similar amounts. The smaller mean $\mathrm{R}_{\mathrm{ap}}(0.37)$ in $\mathrm{AD}$ contrasts with the mean $\mathrm{R}_{\mathrm{ap}}$, otherwise, that only differed few hundredths from a mean of 0.6. Hence, coarse absorbing particles in $\mathrm{AD}$ produced $63 \%$ of the absorption. Therefore, if the absorption by fine $\mathrm{AD}$ particles was due

25 to soot, or the $\mathrm{AD}$ fine mode, or a mix of these two, the result implies that absorption by the coarse iron oxides surpassed the absorption by the fine. A question arising is: Why are absorbing aerosols smaller in VA than in $\mathrm{AD}$ if both are iron oxides? One explanation is that VA aerosols are generated by a mechanism in which aerosols are heated to elevated temperature.

These results also show that coarse aerosols produced most of the extinction in Puerto Rico within the MBL and support the importance of the SAL as a transport mechanism allowing coarse aerosols to move from the Sahara to the Caribbean and

30 farther to Miami (Prospero, 1999), after their lift to high altitudes. Our methods to segregate the sub-micron particles from the total allowed us to measure what fraction of the total scattering and absorption was due to sub-micron aerosols. 
Atmos. Chem. Phys. Discuss., https://doi.org/10.5194/acp-2017-703

Manuscript under review for journal Atmos. Chem. Phys.

Chemistry

Discussion started: 18 September 2017

(c) Author(s) 2017. CC BY 4.0 License.

and Physics

Discussions

(c) (i)

A surface mean $R_{s p}$ of 0.2 and a columnar mean $\delta_{\mathrm{ae}} \mathrm{FF}$ of 0.27 agree that coarse aerosols produced most of the scattering within the MBL and most of the columnar extinction in Puerto Rico. But the overall mean $\mathrm{R}_{\mathrm{sp}}$ was $35 \%$ smaller than the columnar mean $\delta_{\mathrm{ae}} \mathrm{FF}$, implying that the size distributions at the surface vs. column average are a major contribution to this difference. Another contributor is the difference in the sizes separating the columnar fine/coarse $\delta_{a e}$ and surface submicron/super-micron scattering or absorption. The size cut for surface data is $1 \mu \mathrm{m}$ aerodynamic diameter corresponding to $0.7 \mu \mathrm{m}$ geometric diameter for a particle density of 2.0. The AERONET "size cut" is poorly defined, but is larger than 0.7 $\mu \mathrm{m}$ geometric diameter. Also, the difference in relative humidity aloft vs. at the surface, as well as the wavelengths used to calculate $\delta_{\mathrm{ae}} \mathrm{FF}$ and $\mathrm{R}_{\mathrm{sp}}$, may have contributed to the difference.

\subsubsection{Single Scattering Albedo $\left(\omega_{0}\right)$}

10 The difference between mean $\omega_{0}$ in $\mathrm{AD}$ and VA was nonsignificant, even though the means of $\sigma_{\mathrm{sp}}$ and $\sigma_{\mathrm{ap}}$ serving to derive $\omega_{0}$, were significantly greater in $\mathrm{AD}$. Also, the absorbing particles were significantly larger in $\mathrm{AD}$ than the absorbing particles in VA. The mean $\omega_{0}$ for marine aerosols was $\sim 0.99$. We calculated the uncertainty in $\sigma_{\mathrm{ap}}$ associated with the calibration constants in Eqn. (1) $\left(\sigma_{\text {meas }}=\mathrm{K}_{1} \sigma_{\mathrm{sp}}+\mathrm{K}_{2} \sigma_{\mathrm{ap}}\right)$ of Bond et al. (1999), including the adjustment by Ogren (2010), with $\sigma_{\text {meas, }}$ the apparent absorption. In this adjustment, $K_{2}=1.44 \pm 0.24$ and $K_{1}=0.02 \pm 0.02$ such as in Bond et al. (1999).

15 With $a$ defined as a $=\frac{\omega_{0}}{1-\omega_{0}}=\frac{\sigma_{\text {sp }}}{\sigma_{\text {ap }}}$, and the equation for the uncertainty, $\frac{\sigma_{a p, c a l}}{\sigma_{a p}}=\frac{\left(\left(a * \Delta K_{1}\right)^{2}+\left(\Delta K_{2}\right)^{2}\right)^{1 / 2}}{\left(a * K_{1}+K_{2}\right)^{2}}$, we obtained $\frac{\sigma_{a p, c a l}}{\sigma_{a p}}=$ $\frac{\left(\left(0.02 * \frac{\omega_{0}}{1-\omega_{0}}\right)^{2}+(0.24)^{2}\right)^{1 / 2}}{\left(0.02 * \frac{\omega_{0}}{1-\omega_{0}}+1.44\right)^{2}}=17 \%$ for marine aerosols with Eqn. (S4c) in Sherman et al. (2015). The term $\sigma_{\text {ap,cal }}$ is the uncertainty in $\sigma_{a p}$ resulting from uncertainties in the calibration constants and $\sigma_{a p}$ is the absorption coefficient. Mean $\omega_{0}$ was 0.96 in $\mathrm{AD}$ and $\mathrm{VA}$, with a relative uncertainty of $15 \%$. The uncertainty in $\sigma_{\text {meas }}$ also contributes to the total uncertainty of $\Delta \sigma_{\mathrm{ap}} / \sigma_{\mathrm{ap}}$ and $\Delta \omega_{0} / \omega_{0}$. Uncertainties larger than 0.01 in $\Delta \omega_{0} / \omega_{0}$ would yield an $\omega_{0}$ larger than one, which is physically 20 impossible. From these results, the marine aerosols absorption coefficient could be zero. If the $95 \%$ CI for $\omega_{0}$ includes values larger than 1.0, we cannot reject the hypothesis that marine aerosols are non-absorbing. Even though values of $\omega_{0}$ above 1.0 are physically impossible, the measurement techniques, which are difference-based, means that measured values above 1.0 are possible. To analyze the dependence of $\omega_{0}$ on the particle size, we plotted $\omega_{0}$ vs. å in Figure 8 . We found a very weak dependence that may have to do with absorbing particles not only in the fine mode but also in the coarse mode

25 (Figure 8). Also, results for $\mathrm{R}_{\mathrm{ap}}$ showed coarse $\mathrm{AD}$ aerosols having the greatest absorption. Smaller $\omega_{0}$ and å in Figure 8 suggests absorption by coarse aerosols such as the iron oxides in $\mathrm{AD}$ (Moosmüller et al. (2009). Our results for $\omega_{0}$ in $\mathrm{AD}$ (0.96) supports the findings by E. A. Reid (2003) that reported that elemental iron composes $\sim 2.5-3 \%$ of the total dust mass. 
Atmos. Chem. Phys. Discuss., https://doi.org/10.5194/acp-2017-703

Manuscript under review for journal Atmos. Chem. Phys.

Chemistry

Discussion started: 18 September 2017

(c) Author(s) 2017. CC BY 4.0 License.

and Physics

Discussions

(c) (i)

\subsubsection{Radiative Forcing Efficiency $\left(\Delta R F / \delta_{a e}\right)$}

The mean radiative forcing efficiency $\left(\Delta \mathrm{RF} / \delta_{\mathrm{ae}}\right)$ was significantly different among air masses. For instance, mean $\Delta \mathrm{RF} / \delta_{\mathrm{ae}}$ in $\mathrm{AD}$ was significantly greater (about $2 \mathrm{~W} \mathrm{~m}^{-2}$ ) than that of $\mathrm{CM}$, and $\sim 1 \mathrm{~W} \mathrm{~m}^{-2}$ greater than those of CMS and VA. To compare the radiative cooling of $\mathrm{AD}$ and $\mathrm{VA}$, we first calculated the average of $\Delta \mathrm{RF} / \delta_{\mathrm{ae}}$ and $\delta_{\mathrm{ae}}$ for the period and then

5 found the product of the two averages for $\mathrm{AD}$ and VA. We obtained a mean radiative cooling of $-11.7 \mathrm{~W} \mathrm{~m}^{-2}$ for $\mathrm{AD}$ and -5.7 $\mathrm{W} \mathrm{m}{ }^{-2}$ for VA. Equivalently, $\mathrm{AD}$ produced around twice the cooling of VA at the top of the atmosphere, despite that $\mathrm{AD}$ produced a greater local heating rate due to absorption. Examining how $\Delta \mathrm{RF} / \delta_{\mathrm{ae}}$ varies with the aerosol load, we plotted $\Delta \mathrm{RF} / \delta_{\mathrm{ae}}$ vs. $\sigma_{\mathrm{sp}}$ (Figure 9a). Figure $9 \mathrm{a}$ shows that $\Delta \mathrm{RF} / \delta_{\mathrm{ae}}$ varies more the first $5-45 \mathrm{Mm}^{-1}$. In section 3.3 .1 we found a lognormal distribution for $\sigma_{\mathrm{sp}}$. Therefore, one explanation for the large variability of $\Delta \mathrm{RF} / \delta_{\mathrm{ae}}$ is that the log-normal, skewed to

10 the right distribution of $\sigma_{\mathrm{sp}}$, creates a non-linear relation between $\sigma_{\mathrm{sp}}$ and $\Delta \mathrm{RF} / \delta_{\mathrm{ae}}$. To make the relation linear, we transformed $\sigma_{\mathrm{sp}}$ in $\log \left(\sigma_{\mathrm{sp}}\right)$, where $\log \left(\sigma_{\mathrm{sp}}\right)$ is the natural logarithm of $\sigma_{\mathrm{sp}}$. Figure $9 \mathrm{~b}$ shows a linear-log regression model of the form, $\frac{\Delta \mathrm{RF}}{\delta \mathrm{ae}}=\alpha+\beta \log \sigma_{\mathrm{sp}}$ with $\alpha=-30.7 \mathrm{~W} \mathrm{~m}^{-2}$, the intercept in the vertical axis and $\beta=1.15$, the slope of the line. The model predicts that an increase of $\log \sigma_{\mathrm{sp}}$ by one unit, changes $\Delta \mathrm{RF} / \delta_{\mathrm{ae}}$ by 1.15 . Substituting the smallest measured scattering coefficient $\sigma_{\mathrm{sp}}$ of around $10 \mathrm{Mm}^{-1}$ in the regression model gives $\frac{\Delta \mathrm{RF}}{\delta \mathrm{ae}} \sim-28 \mathrm{~W} \mathrm{~m}^{-2}$. An increase of $20 \%$ in $\sigma_{\mathrm{sp}}=10$

$15 \mathrm{Mm}^{-1}$ would result in $\frac{\Delta \mathrm{RF}}{\delta \mathrm{ae}}=-30.7 \mathrm{~W} \mathrm{~m}^{-2}+1.15 \log (1.2 * 10) \mathrm{W} \mathrm{m}^{-2}=-28 \mathrm{~W} \mathrm{~m}^{-2}+0.21 \mathrm{~W} \mathrm{~m}^{-2}$. Therefore, an increase of $20 \%$ in $\sigma_{\mathrm{sp}}$ would result in $0.21 \mathrm{~W} \mathrm{~m}^{-2}$ increase of $\Delta \mathrm{RF} / \delta_{\mathrm{aee}}$. We thus showed that greater loadings of $\mathrm{AD}$ aerosols caused greater radiational cooling at the top of the atmosphere and greatest local heating within the MBL and that $\Delta \mathrm{RF} / \delta_{\mathrm{ae}}$ depends on the aerosol loading. We also estimated the increase in $\Delta \mathrm{RF} / \delta_{\mathrm{ae}}$ as $\sigma_{\mathrm{sp}}$ increase by a certain percent.

Eqn. 6 shows that $\Delta \mathrm{RF} / \delta_{\mathrm{ae}}$ also depends on two aerosol properties, single-scattering albedo $\left(\omega_{0}\right)$ and upscatter fraction $(\beta)$.

20 To diagnose the overall relation in Figure $9 \mathrm{a}$, we plotted the relation between $\Delta \mathrm{RF} / \delta_{\mathrm{ae}}$ and these two aerosol variables separately (Fig 10 and Fig 11). The results show a clear dependence of $\Delta \mathrm{RF} / \delta_{\text {ae }}$ on the upscatter fraction, illustrating the importance of knowing the backscatter fraction to calculate it and the importance of the aerosols' sizes. A clear dependence of $\Delta \mathrm{RF} / \delta_{\mathrm{ae}}$ on $\omega_{0}$ is not seen in Fig. 11. Summarizing, we found that besides the effects of the upscatter fraction and single scattering albedo, the aerosol loading accounted for around $50 \%$ of the change in the radiative forcing efficiency.

\subsection{Monthly climatology}

In this section, we discuss the monthly variation of aerosols climate-forcing properties in Puerto Rico. We focus on the aerosol loading, on particle size, and on absorbing aerosols. The upper and lower whiskers in the statistical plots are the monthly maximum and minimum; the box upper edge is the $75^{\text {th }}$ percentile, the lower edge is the $25^{\text {th }}$ percentile; the dot is the mean and the horizontal line in the box is the median. 
Atmos. Chem. Phys. Discuss., https://doi.org/10.5194/acp-2017-703

Manuscript under review for journal Atmos. Chem. Phys.

Discussion started: 18 September 2017

(c) Author(s) 2017. CC BY 4.0 License.

Note that mean $\sigma_{\mathrm{sp}}$ and $\delta_{\mathrm{ae}}$ peaks in summer due to $\mathrm{AD}$ (Figure 12 (a) and (b)). The monthly variation of $\sigma_{\mathrm{sp}}$ peaks in June and the mean variation of $\delta_{\text {ae }}$ peaks in July. Two explanations for the difference in timing of the maxima are: 1) we recorded $\sigma_{\mathrm{sp}}$ at controlled RH and the AERONET assessed $\delta_{\mathrm{ae}}$ at ambient RH and 2), the transport aloft brings different amounts of aerosols than the transport in the MBL. The result is consistent with Reid et al. (2002) that reported highest dust concentrations in the MBL in June. The climatology of $\sigma_{\mathrm{sp}}$ and $\delta_{\mathrm{ae}}$ also agrees with Prospero (1999) that the seasonality of $\mathrm{AD}$ peaks in summer.

Mean $\sigma_{\mathrm{ap}}$ was smaller in July than in other months (Figure 13) implying that most of the absorbing aerosols are above the MBL as suggested by the greatest columnar $\delta_{\mathrm{ae}}$. The maximum value of $\sigma_{\mathrm{ap}}$ in May 8, 2008 was due to an $\mathrm{AD}$ event. Because on May 7, 2008 we sensed VA at CPR and $\sigma_{a p}$ is extensive and additive, this high value may have to do with VA, although $10 \mathrm{VA}$, if any, was underneath the $\mathrm{AD}$. The absorption increased from $0.8 \mathrm{Mm}^{-1}$ on May 6 , to $6 \mathrm{Mm}^{-1}$ on May 7 and $10.8 \mathrm{Mm}^{-1}$ on May 8. The corresponding $\sigma_{\mathrm{sp}}$ increased from 65 to 165 to $219 \mathrm{Mm}^{-1}$ for the same days. The maximum $\sigma_{\mathrm{ap}}$ in May 8, 2008 could be due to the $\sigma_{\mathrm{ap}}$ of $\mathrm{AD}$ added to the $\sigma_{\mathrm{ap}}$ of VA because $\sigma_{\mathrm{ap}}$ is extensive and extensive properties are additive.

Black carbon (BC) from forest fires in Brazil may have to do with the greater mean $\sigma_{\mathrm{ap}}$ in September and October. We based this statement on the trajectories, forest fires in Brazil, and the southern long-range transport due to cyclones over the 15 Atlantic. Absorption of 6 to $7 \mathrm{Mm}^{-1}$ had corresponding $\sigma_{\mathrm{sp}}$ of 35 to $37 \mathrm{Mm}^{-1}$. Hence, greater absorption in September and October may have to do with BC from the forest fires in SA. We saw this transport three days in October and two days in September.

The low mean $\mathrm{R}_{\mathrm{sp}}$ in Figure 14 (a) shows small variations through the year, suggesting that coarse marine aerosols are always present in Puerto Rico. The lower monthly mean $\mathrm{R}_{\mathrm{sp}}$ in in June and July suggests more coarse AD aerosols arriving

20 to the MBL enhancing the coarse marine aerosols. From March to May, and in September and October, a greater mean $R_{s p}$ suggests a smaller fraction of coarse particles. The $R_{s p}$ monthly variation at the surface resembles the monthly variation of the columnar $\delta_{\mathrm{ae}} \mathrm{FF}$ (Figures 14 (a) and (b)). Namely, smaller mean $\mathrm{R}_{\mathrm{sp}}$ and $\delta_{\mathrm{ae}} \mathrm{FF}$ in July, suggest more coarse mode scattering particles within the MBL and columnar, in July. Due to the continuous release of coarse sea-salt particles at the surface, the mean monthly $\mathrm{R}_{\mathrm{sp}}$ was lower than that of $\delta_{\mathrm{ae}} \mathrm{FF}$ through the year. The two parameters have low values showing

25 that coarse aerosols (such as marine) dominated the scattering within the MBL and extinction in the atmospheric column. The AD coarse mode enhanced the marine coarse mode in summer as shown by the lower values $\mathrm{R}_{\mathrm{sp}}$ and $\delta_{\mathrm{ae}} \mathrm{FF}$.

Absorbing particles were mostly sub-micron from January to May and in December (Figure 15). Even though the dust season peaks in summer, the easterlies shape the local weather until November, suggesting that coarse AD aerosols dominated and caused a low mean $\mathrm{R}_{\mathrm{ap}}$ from June to November within the MBL. This result agrees with Prospero et al.

30 (1970) and Prospero and Carlson (1972) that synoptic outbreaks of Saharan dust occur from late spring to fall. Volcanic ash caused the greatest mean $\mathrm{R}_{\mathrm{ap}}$ of around 0.7 and a maximum $R_{a p}$ of 0.95 on March 24, 2008.

About the monthly climatology of $\omega_{0}$ in Figure 16 (a), we noted that September had the smallest mean $\omega_{0}$ and the median $\omega_{0}$ throughout the year stayed greater than 0.96. December, January, February, and March had mean monthly $\omega_{0}$ of $\sim 0.97$. This result implies that marine aerosols are always present and are thus important for the radiative balance. The lowest mean $\omega_{0}$ 
Atmos. Chem. Phys. Discuss., https://doi.org/10.5194/acp-2017-703

Manuscript under review for journal Atmos. Chem. Phys.

Chemistry

Discussion started: 18 September 2017

(c) Author(s) 2017. CC BY 4.0 License.

and Physics

Discussions

(c) (i)

occurred in September with a mean of 0.95 and minimum about 0.90 . The monthly variability of the radiative forcing efficiency $\left(\Delta \mathrm{RF} / \delta_{\mathrm{ae}}\right)$ throughout the year was larger in March, April, and May (Figure 16 (b)). The variability in the mean $\Delta \mathrm{RF} / \delta_{\mathrm{ae}}$ was small through from $2006-2010$. The larger range in these months may be caused by the combined effects of the fine, absorbing particles of volcanic ash and the coarse, less absorbing marine aerosol. Monthly means, however, varied

$5 \quad$ little $\left(27 \pm 1 \mathrm{~W} \mathrm{~m}^{-2}\right)$.

\section{Conclusions}

We presented a method to classify natural aerosols by source in Puerto Rico and analyzed the means and variability of the radiative-forcing properties of these aerosols. Mean loads, sizes, and absorbing properties were different among aerosols in Puerto Rico at $\mathrm{p}<0.05$. The radiative forcing properties were different not only within the MBL, but also in the atmospheric column. Therefore, we accepted our hypothesis for the parameters associated with the loads and sizes at the surface and columnar. We rejected the hypothesis for differences in the single scattering albedo between African dust and volcanic ash. However, the parameters computed with the single scattering albedo and the parameters used to compute the single scattering albedo were different.

The absorbing particles in African dust were larger than the absorbing particles in volcanic ash. Even though smaller sizes

15 (as in volcanic ash) have greater scattering efficiency, African dust produced a greater radiative cooling due to their greater loads. African dust could produce a local heating rate $50 \%$ greater than that of volcanic ash because of greater absorption coefficient. However, we could not distinguish among aerosols of different air masses only knowing their means and variability because their frequency distributions overlap much.

Despite the uncertainty, our method to classify aerosols can, on average, contribute to classify and understand the means and

20 variability in the radiative-forcing properties. Also, our results agree with the empirical evidence cited from earlier results allowing us to conclude that our classification method is proper. We also presented the monthly climatology of aerosols radiative-forcing properties in Puerto Rico. Size-resolved measurements showed that the coarse mode dominated the scattering and absorption in African dust. Coarse marine aerosols dominated the volume (and mass) because they are near the source at the surface, despite falling faster than AD aerosols with a smaller size mode. Trajectories (Table 1) showed that

$25 \mathrm{AD}$ aerosols last $\sim 5$-7 days to reach CPR. The continuous production at the surface makes marine aerosols important because they are a continuous source of scattering. Continuing efforts to measure or estimate upscatter fraction, such as in Andrews et al. (2006) to estimate the asymmetry factor, would help to decrease the uncertainty in calculated radiative forcing efficiency, because our results showed that variations in upscatter fraction strongly contribute to variations in radiative forcing efficiency. Because different absorbing aerosols cause different changes in temperature, the correct measurement of absorption continues as one key issue in the study of the climate-forcing properties of aerosols. 
Atmos. Chem. Phys. Discuss., https://doi.org/10.5194/acp-2017-703

Manuscript under review for journal Atmos. Chem. Phys.

Discussion started: 18 September 2017

(c) Author(s) 2017. CC BY 4.0 License.

(c) (1)

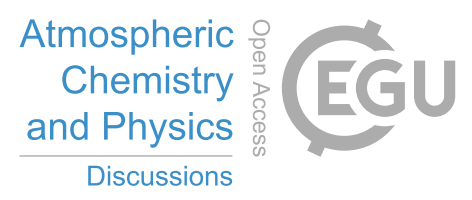

Acknowledgements. We gratefully acknowledge Patrick Sheridan (NOAA), and Anne Jefferson and Derek Hageman

5 (University of Colorado) for their contributions to station operations and data processing, as well as the NOAA Climate Program Office for the funding support. We also acknowledge the NSF AGS 0936879 and the NSF GK-12 Scholarship for their financial support, and the Conservation Trust of Puerto Rico for the use of their facilities at the nature reserve of Cabezas de San Juan. (CSJ). Thanks to the Atmospheric Chemistry and Aerosols Research Group at UPR-RP for their support (especially to Mr. Félix Zürcher, Ian Gutiérrez and Carmelo Costacamps). We thank Gerardo Morell for his financial support through NASA EPSCOR and José F. Nieves for their financial support through Department of Physics PEAFs.

15 
Atmos. Chem. Phys. Discuss., https://doi.org/10.5194/acp-2017-703

Atmospheric

Manuscript under review for journal Atmos. Chem. Phys.

Chemistry

Discussion started: 18 September 2017

(c) Author(s) 2017. CC BY 4.0 License.

and Physics

Discussions

(c) (i)

\section{References}

Anderson, T. and Ogren J. A.: Determining Aerosol Properties Using the TSI 3563 Integrating Nephelometer, Aero. Sci. Tech., 29, 57-69, 1998.

5 Andrews, E., Sheridan, P. J., Fiebig, M., McComiskey, A., Ogren, J. A., Arnott, P., Covert, D., Elleman, R., Gasparini, R., Collins, D., Jonsson, H., Schmid, B., and Wang, J.: Comparison of methods for deriving aerosol asymmetry parameter, J. Geophys. Res.,111,05S04, doi:10.1029/2004JD005734.

Blanchard, D. C. and Woodcock, A. H.: Production, concentration, and vertical distribution of the sea salt aerosols. Ann. N. Y. Acad. Sci 353, 186-200, 1980.

10 Bohren, C. F. and Huffman, D. R.: Absorption and Scattering of Light by Small Particles, John Wiley, Hoboken, N. J, 1983.

Bond, T. C., Anderson, T. L. and Campbell, D.: Calibration and intercomparison of filter-based measurements of visible light absorption by aerosols. Aerosol Sci. Technol., 30, 582-600, 1999.

Charlson, R. J., Langner, J., Rodhe, H., Leovy, C. B., and S.G. Warren, S. G.: Perturbation of the Northern Hemisphere Radiative Balance by Backscattering from Anthropogenic Sulfate Aerosols, Tellus 43AB (4):152-163, 1991.

15 Delene, D. J. and Ogren, J. A.: Variability of Aerosol Optical Properties at Four North American Surface Monitoring Sites, J. Atmos. Sci., 59, 1135-1150, 2002.

Denjean, C., Formenti, P., Desboeufs, K, Che vaillier, S., Triquet, S., Maillé, M., Cazaunau, M., Laurent, B., Mayol-Bracero, O. L., Vallejo, P., Quiñones, M., Gutierrez, I., Cassola, F., Prati, P., Ogren, J. A., and Andrews, E.: Size distribution and optical properties of African mineral dust after intercontinental transport, J. Geophys. Res. Atmos., 121, 7117-7138, doi:10.1002/2016JD024783, 2016.

Draxler, R. R. and Hess G. D.: An overview of the HYSPLIT_4 modelling system for trajectories, dispersion and deposition, Aust. Met. Mag., 47, 295-308, 1998.

Draxler, R. R. and Rolph, G. D.: HYSPLIT (HYbrid Single-Particle Lagrangian Integrated Trajectory) Model access via NOAA ARL READY Website (http://ready.arl.noaa.gov/HYSPLIT.php). NOAA Air Resources Laboratory, Silver Spring,

25 MD, 2013.

Dubovik, O. and King, M. D.: A flexible inversion algorithm for retrieval of aerosols optical properties from sun and sky radiance measurements, J. Geophys. Res., 105, D16, 20673, 2000.

Fitzgerald, E., Ault, A. P., Zauscher, M., Mayol-Bracero, O. L. and Prather, K. A.: Comparison of the Mixing State of Longrange Transported Asian and African Mineral Dust. Atmos. Environ. 115: 19-25, 2015.

30 Gioda, A., Reyes-Rodríguez, G. J., Santos-Figueroa, G., Collet Jr., J. L., Decesari, S., da Conceição, M., Ramos, K. V., Bezerra-Netto, H. J., de Aquino-Neto, F. R. and Mayol-Bracero, O. L.: Speciation of Water-soluble Inorganic, Organic, and 
Atmos. Chem. Phys. Discuss., https://doi.org/10.5194/acp-2017-703

Atmospheric

Manuscript under review for journal Atmos. Chem. Phys.

Chemistry

Discussion started: 18 September 2017

(C) Author(s) 2017. CC BY 4.0 License.

and Physics

Discussions

(c) (i)

Total Nitrogen in a Background Environment: Cloud Water, Rainwater, and Aerosol Particles. J. Geophys. Res. 116: 05203, doi: 10.1029/2010JD015010, 2011.

Haywood, J. M. and Shine, K. P.: The effect of anthropogenic sulphate and soot aerosol on the clear sky planetary radiation budget, Geophys. Res. Lett. 22, 603-606, 1995.

5 Holben, B. N., Eck, T. F., Slutsker, I., Tanre, D., Buis, J. P., Setzer, A., Vermote, E., Reagan, J. A., Kaufman, Y. J., Nakajima, T., Lavenu, F., Jankowiak, F., and Smirnov, A.: AERONET - A federated instrument network and data archive for aerosol characterization, Remote Sens. Environ., 66, 1-16, 1998.

Holben, B. N., Eck, T. F., Slutsker, I., Smirnov, A., Sinyuk, A., Schafer, J., Giles, D., and Dubovik, O.: AERONET's Version 2.0 quality assurance criteria, in Remote Sensing of the Atmosphere and Clouds, edited by S.-C. Tsay et al., Proc.

10 SPIE, 6408, 64080Q, doi: 10.1117/12.706524, 2006.

Houghton, J. T., Ding, Y., Griggs, D. J., Noguer, M., Van der Linden, P. J., Dai, X., Maskell, K, and Johnson, C. A.: Climate Change 2001, The Scientific Basis, Cambridge Univ. Press, Cambridge, U.K., 2001.

Housley, D., Bérubé, K. A., Jones, T. P., Anderson, S., Pooley, F. D., and Richards, R. J.: Pulmonary epithelial response in the rat lung to instilled Montserrat respirable dusts and their major mineral components, Occup. Environ. Med., 59, 466-472,

2002.

Huneeus, N., Schulz, M., Balkanski, Y., Griesfeller, J., Kinne, S., Prospero, J., Bauer, S., Boucher, O., Chin, M., Dentener, M. F., Diehl, T., Easter, R., D. Fillmore, D., Ghan, S., Ginoux, P., Grini, A., Horowitz, L., Koch, D., Krol, M. C., Landing, W, Liu, X., Mahowald, N., Miller, R. L., Morcrette, J., G. Myhre, G., J.E. Penner, J. E., Perlwitz, J. P., Stier, P., Takemura, T., and C. Zender, C.: Global dust model intercomparison in AeroCom phase I. Atmos. Chem. Phys., 11, 7781-7816, 20 doi:10.5194/acp-11-7781, 2011.

IPCC: Climate Change 2001: The Scientific Basis. In: Contribution of Working Group I to the Third Assessment Report of the Intergovernmental Panel on Climate Change (eds Houghton, J. T., Ding, Y., D. J. Griggs, D. J., Noguer, M., and van der Linden, P. J., 2001.

IPCC: Climate Change 2013: The Physical Science Basis. Contribution of Working Group I to the Fifth Assessment Report

of the Intergovernmental Panel on Climate Change, Stocker, T. F., Qin, D, Plattner, G. K., Tignor, M., Allen, S. K., Boschung, J., Nauels, A., Xia, Y., Bex, V., and Midgley, P. M., (eds.).: Cambridge University Press, Cambridge, United Kingdom and New York, NY, USA, 2013.

Jacobson, M. Z:: Strong radiative heating due to the mixing state of black carbon in atmospheric aerosols, Nature, 409, 695$697,2001$.

30 Karyampudi, V. M. and Carlson, T. N.: Analysis and numerical simulations of the Saharan Air Layer and its effect on easterly wave disturbances. J. Atmos. Sci., 45, 3102-3136, 1988.

Kleefeld, S, Hoffer, A, Krivácsy, Z, and Jennings, S.G.: Importance of organic and black carbon in atmospheric aerosols at Mace Head, on the west coast of Ireland (53 $\left.{ }^{\circ} 19^{\prime} \mathrm{N}, 9^{\circ} 54^{\prime} \mathrm{W}\right)$. Atmospheric Environment 36:4479-90, 2002. 
Atmos. Chem. Phys. Discuss., https://doi.org/10.5194/acp-2017-703

Atmospheric

Manuscript under review for journal Atmos. Chem. Phys.

Chemistry

Discussion started: 18 September 2017

(C) Author(s) 2017. CC BY 4.0 License.

and Physics

Discussions

(c) (i)

Kokhanovsky, A. A.: Aerosol Optics, Light Absorption and Scattering by Particles in the Atmosphere, 1st ed., 1, 1-15, Berlin, Heidelberg: Praxis Publishing Ltd, 2008.

Krotkov, N., Torres O., Seftor, C., Krueger, A. J., Kostinski, A., Rose, W. I., Bluth, J. F. S, Schneider, D., and Schaefer, S. J.: Comparison of TOMS and AVHRR volcanic ash retrievals from the August 1992 eruption of Mt. Spurr, Geophys. Res.

5 Lett., 26, 455-458, 1999.

Lewis, E. R. and Schwartz, S. E.: Sea Salt Aerosol Production: Mechanisms, Methods, Measurements, and Models - A Critical Review, Geophysical monograph 152, American Geophysical Union, Washington, DC, 413 pp., 2004.

Liao, H. and Seinfeld, J. H.: Effect of Clouds on Direct Aerosol Radiative Forcing of Climate, J. Geophys. Res., 103, 3781$3788,1998$.

10 Li-Jones, X. and Prospero, J. M.: Variations in the size distributions of non-sea-salt sulfate aerosol in the marine boundary layer at Barbados: Impact of African dust, J. Geophys. Res. 103, 16073-16084, 1998.

Lovett, R. F.: Quantitative measurement of airborne sea-salt in the North Atlantic, Tellus, 30, 358-363, 1978.

Moosmüller, H., Chakrabarty, R. K., and Arnott, W. P.: Aerosol Light Absorption and its Measurement: A Review, J. Quant. Spectrosc. Ra., 110, 844-878, 2009.

15 O’Dowd, C. D. and Smith M. H.: Physicochemical properties of aerosols over the Northeast Atlantic: Evidence for windspeed-related submicron sea-salt aerosol production, J. Geophys. Res., doi: 10.1029/92JD02302,1137-1149, 1993.

O’Dowd, C. D., Facchini, M. C., Cavalli F., Ceburnis, D., Mircea, M., Decesari, S., Fuzzi, S., Yoon, Y. J., and Putaud, J.: Biogenically driven organic contribution to marine aerosol, Nature, 431, 676-680, doi: 10.1038/nature02959., 2004.

Ogren, J. A.: In situ observations of aerosol properties, in Aerosol Forcing of Climate, edited by R. J. Charlson and J.

20 Heintzenberg, pp. 215-226, John Wiley, Hoboken, N. J., 1995.

Ogren, J. A.: Comment on "Calibration and Intercomparison of filter-based measurements of visible light absorption by aerosols. Aerosol Sci. and Technol., 44, 589-591, 2010.

O'Neill, N. T., Dubovik, O., and Eck, T. F.: A modified Angstrom coefficient for the characterization of sub-micron aerosols, App. Opt., Vol. 40, No. 15, pp. 2368-2374, 2001.

25 O'Neill, N. T., Eck, T. F., A. Smirnov, A., B. Holben, and N. Thulasiraman, S.: Spectral discrimination of coarse and fine mode optical depth, Vol., 108, J. Geophys. Res., No. D17, 4559-4573, 10.1029/2002JD002975, 2003.

Prospero, J. M., Bonatti, E., Schubert, C., and Carlson, T. N.: Dust in the Caribbean atmosphere traced to an African dust storm, Earth Planet. Sci. Lett., 9, 287-293, 1970.

Prospero, J. and Carlson, T.: Vertical and areal distribution of Saharan dust over the western equatorial North Atlantic

Ocean, J. Geophys. Res., 77, 5255-5265, doi: 10.1029/JC077i027p05255, 1972.

Prospero, J.: Long-Term measurements of the transport of African mineral dust to the south-eastern United States: Implications for regional air quality, J. Geophys. Res., 104, 15917-15927, 1999.

Prospero, J. M. and Mayol-Bracero, O. L.: Understanding the Transport and Impact of African Dust on the Caribbean Basin. Bull. Am. Meteorol. Soc. 94: 1329-1337, 2013. 
Atmos. Chem. Phys. Discuss., https://doi.org/10.5194/acp-2017-703

Atmospheric

Manuscript under review for journal Atmos. Chem. Phys.

Chemistry

Discussion started: 18 September 2017

(C) Author(s) 2017. CC BY 4.0 License.

and Physics

Discussions

(c) $\underset{\mathrm{Br}}{\mathrm{B}}$

Quinn, P. K., Anderson, T., Bates, T., Dlugi, R., Heintzenberg, J., Von Hoyningen-Huene, W., Kumula, M., Russel, P., and Swietlicki, E.: Closure in tropospheric aerosol-climate research: A review and future needs for addressing aerosol direct shortwave radiative forcing. Contrib. Atmosph. Phys., 69, 547-34 577, 1996.

Quinn, P. K. and Coffman, D. J.: Comment on 'Contribution of different aerosols species to the global aerosol extinction optical thickness: Estimates from model results” by Tegen et al., J. Geophys. Res., 104, 4241-4248, 1999.

Raga, G. B., Baumgardner, D., and Mayol-Bracero, O. L.: History of Aerosol-Cloud Interactions Derived from Observations in Mountaintop Clouds in Puerto Rico. Aerosol Air Qual. Res., 16, 674-688, doi:10.4209/aaqr.2015.05.0359, 2016.

Reid, J. S., Westphal, D. L., Livingston, J. M., Savoie, D. L., Maring, H. B. Jonsson, H. H., Eleuterio, D. P., Kinney, J. E., and Reid, E. A.: Dust vertical distribution in the Caribbean during the Puerto Rico Dust Experiment, Geophys. Res. Lett., 10 29(7), 1151, doi:10.1029/2001GL014092, 2002.

Reid, E. A., Reid, J. S., Broumas, A. P., Cliff, S. S., Meyer, M. M., Dunlop, M., Cliff, S. S., Broumas, A., Perry, K. D., and Maring, H.: Characterization of African dust transported to Puerto Rico by individual particle and size segregated bulk analysis, J. Geophys. Res., 108(D19), 8591, 2003.

Reid, J. S., Jonsson, H. H., Maring, H. B., Smirnov, A., Savoie, D. L., Cliff, S. S., Reid, E. A., Livingston, J. M., Meier, M.

15 M., Dubovik, O., and Tsay S. C.: Comparison of size and morphological measurements of coarse mode dust particles from Africa, J. Geophys. Res., 108, D19, 8593, doi: 10.1029/2002JD002485, 2003b.

Reid, J. S., Kinney, J. E., Westphal, D. L., Holben, B. N., Welton, E. J., Tsay, S. C., Eleuterio, D. P., Campbell, J. R., Christopher, A., Colarco, P. R., Jonsson, H. H., Livingston, J. M., Maring, H. B., Meier, M. L., Pilewskie, P., Prospero, J. M., Reid, E. A., Remer, L. A., Russell, P. B., Savoie, D. L., Smirnov, A., and Tanre', D.: Analysis of measurements of

20 Saharan dust by airborne and ground-based remote sensing methods during the Puerto Rico Dust Experiment (PRIDE), J. Geophys. Res., 58, D19, 8586, doi: 10.1029/2002JD002493, 2003a.

Seinfeld, J. H. and Pandis S. N.: Atmospheric Chemistry and Physics: from Air Pollution to Climate Change, Wiley, New York, 1998.

Sheridan, P. J. and Ogren, J. A.: Observations of the vertical and regional variability of aerosol optical properties over central and eastern North America. J. Geophys. Res., 104, 16 793-16 805, 1999.

Sherman, J. P., Sheridan, P. J., Ogren, J. A., Andrews, E., Hageman, D., Schmeisser, L., Jefferson, A. and Sharma, S.: A multi-year study of lower tropospheric aerosol variability and systematic relationships from four North American regions, Atmos. Chem. Phys., 15, 12487-12517, doi:10.5194/acp-15-12487, 2015.

Smirnov, A., Holben, B. N., Eck, T. F., Dubovik, O., and Slutsker, I.: Effect of wind speed on columnar aerosol optical

30 properties at Midway Island, J. Geophys. Res., 108, 4802, doi:10.1029/2003JD003879, 2003.

Sokolik, I. N. and Toon, O. B.: Incorporation of mineralogical composition into models of the radiative properties of mineral aerosols from UV to IR wavelengths, J. Geophys. Res., 104, 9423-9444, 1999. 
Atmos. Chem. Phys. Discuss., https://doi.org/10.5194/acp-2017-703

Manuscript under review for journal Atmos. Chem. Phys.

Discussion started: 18 September 2017

(c) Author(s) 2017. CC BY 4.0 License.
Atmospheric

Chemistry

and Physics

Discussions

(c) (i)

Sokolik, I., Winker, D. M., Bergametti, G., Gillettce, D., Carmichael, G., Kaufman, Y. J., Gomes, L., Schuetz, L., and Penner, J. E.: Introduction to special section: Outstanding problems in quantifying the radiative impacts of mineral dust, J. Geophys. Res., 106, D16, 18015-18028, 2001.

Spiegel, J. K., Buchmann, N., Mayol-Bracero, O. L., Cuadra-Rodríguez, L. A., Valle-Díaz, C. J., Prather, K. A., Mertes, S. 5 and Eugster, W.: Do Cloud Properties in a Puerto Rican Tropical Montane Cloud Forest Depend on Occurrence of Longrange Transported African Dust? Pure Appl. Geophys. 171: 2443-2459, 2013.

USGS Fact Sheet, Airborne Volcanic Ash-A Global Threat to Aviation, Alaska: USGS, 2006.

Valle-Díaz, C. J., Torres-Delgado, E., Colón-Santos, S. M., T. Lee, T., J.L. Collett Jr., J. L., McDowell, W. H. and MayolBracero, O. M.: Impact of long-range transported African dust on cloud water chemistry at a tropical montane cloud forest in 10 northeastern Puerto Rico. Aerosol and Air Quality Research. DOI: 10.4209/aaqr.2015.05.0320, 2016.

Vinoj, V., Babu, S. S., Satheesh, S. K., Krishna Moorthy, K., and Kaufman, Y. J.: Radiative forcing by aerosols over the Bay of Bengal region derived from shipborne, island-based, and satellite (Moderate-Resolution Imaging Spectroradiometer) observations, J. Geophys. Res., 109, D05203, doi: 10.1029/2003JD004329, 2004.

Warneck, P.: Chemistry of the Natural Atmosphere, San Diego CA, Academic Press, 1988.

15 Wex, H., Dieckmann, K., Roberts, G. C., Conrath, T., Izaguirre, M. A., Hartmann, S., Herenz, P., Schäfer, M., Ditas, F., Schmeissner, T., Henning, S., Wehner, B., Siebert, H., and Stratmann, F.: Aerosol arriving on the Caribbean island of Barbados: physical properties and origin, Atmos. Chem. Phys., 16, 14 107-14 130, doi: 10.5194/acp-16-14107-2016, 2016. Winter, B. and Chylek, P.: Contribution of sea salt aerosol to the planetary clear-sky albedo, Tellus B, 49(1), 72-79, 1997. WMO/GAW Aerosol Measurement Procedures, Guidelines and Recommendations, 2nd Edition, 2016. (GAW No. 227, 20 WMO-No. 1177, http://www.wmo.int/pages/prog/arep/gaw/documents/FINAL_GAW_227.pdf).

Woodcock A. H.: Salt nuclei in marine air as a function of altitude and wind force, J. Meteorol, 10, 362-371, 1953. 
Atmos. Chem. Phys. Discuss., https://doi.org/10.5194/acp-2017-703

Table 1. Summary of the method to classify atmospheric aerosols in Puerto Rico.

Air masses

\begin{tabular}{|c|c|c|c|c|c|c|c|}
\hline Criteria & $\mathrm{CM}$ & CMS & VA & $\mathrm{AD}$ & NA & SA & Unknown \\
\hline$\sigma_{s p}$ & $<20 \mathrm{Mm}^{-1}$ & $>20 \mathrm{Mm}^{-1}$ & N/A & N/A & N/A & N/A & N/A \\
\hline$\sigma_{a p}$ & $<0.6 \mathrm{Mm}^{-1}$ & $<0.6 \mathrm{Mm}^{-1}$ & N/A & N/A & N/A & N/A & N/A \\
\hline$\delta_{a e}$ & $<0.1$ & $>0.1$ & N/A & N/A & N/A & N/A & N/A \\
\hline $\begin{array}{l}\text { HYSPLIT BT } \\
\text { at } 100,500 \text {, } \\
1000 \mathrm{~m}, \mathrm{AG} \\
\text { at } 06 \text { and } 12 \mathrm{Z}\end{array}$ & $\begin{array}{l}\text { Not over land 3-4 } \\
\text { days before } \\
\text { arrival to PR }\end{array}$ & $\begin{array}{l}\text { Not over land } \\
3-4 \text { days } \\
\text { before arrival } \\
\text { to PR }\end{array}$ & $\begin{array}{l}\text { SE or across } \\
\text { VA areas last } \\
1-3 \text { days }\end{array}$ & E-SE last 5-7 days & $\begin{array}{l}\text { NW last } \\
4-7 \text { days }\end{array}$ & SW-SSE & N/A \\
\hline $\begin{array}{l}\text { Cloud streaks } \\
\text { (if present) }\end{array}$ & $\begin{array}{l}\text { WNW-ENE } \\
\text { small }\end{array}$ & $\begin{array}{l}\text { WNW-ENE } \\
\text { elongated }\end{array}$ & SE-NW & E-SE & N/A & N/A & \\
\hline $\begin{array}{l}\text { MODIS } \\
\text { Terra/Aqua }\end{array}$ & $\begin{array}{l}\text { Dark blue ocean } \\
\text { color with a few } \\
\text { or no white caps. }\end{array}$ & $\begin{array}{l}\text { Dark blue } \\
\text { ocean with } \\
\text { larger number } \\
\text { of white caps }\end{array}$ & $\begin{array}{l}\text { Show VA } \\
\text { emissions }\end{array}$ & $\begin{array}{l}\text { Dust observed } \\
\text { leaving Africa 5-7 } \\
\text { days before dust } \\
\text { observed over } \\
\text { CPR. Brown } \\
\text { color. No VA } \\
\text { observed. }\end{array}$ & N/A & N/A & $\begin{array}{l}\text { Overcast } \\
\text { skies } \\
\text { observed or } \\
\text { lack of } \\
\text { MODIS } \\
\text { images }\end{array}$ \\
\hline SAL images & $\begin{array}{l}\text { No dust } \\
\text { suggested over } \\
\text { CPR }\end{array}$ & $\begin{array}{l}\text { No dust } \\
\text { suggested } \\
\text { over CPR }\end{array}$ & $\begin{array}{l}\text { No dust } \\
\text { suggested } \\
\text { over CPR }\end{array}$ & $\begin{array}{l}\text { Dust suggested } \\
\text { over CPR }\end{array}$ & $\begin{array}{l}\text { No dust } \\
\text { suggested } \\
\text { over CPR }\end{array}$ & $\begin{array}{l}\text { No dust } \\
\text { suggested } \\
\text { over CPR }\end{array}$ & N/A \\
\hline
\end{tabular}

CM is clean marine, CMS is clean marine with greater sea salt content, VA is volcanic ash, AD is African dust, NA is North America, SA is South America. Unknown means the air mass could not be defined. 
Table 2. Aerosol optical properties by air mass types. Overall measurement results for means \pm standard deviation. Values in parenthesis are the number of daily averages. The left column says

5 if the variable is extensive, intensive, at the surface or columnar. All calculated values are for $\lambda=\mathbf{5 5 0}$ $\mathrm{nm}$ except $\stackrel{a}{a}$ and $\sigma_{a p}$, calculated for the $550 / 700 \mathrm{~nm}$ wavelength pair. $\delta_{a e}$ was assessed at $500 \mathrm{~nm}$.

\begin{tabular}{|c|c|c|c|c|c|}
\hline \multicolumn{6}{|c|}{ Air masses } \\
\hline $\begin{array}{r}\text { 1. Extensive } \\
\text { a.surface }\end{array}$ & CM & CMS & VA & AD & ALL \\
\hline$\sigma_{s p}\left(\mathrm{Mm}^{-1}\right)$ & $15.6 \pm 3.21(110)$ & $27.3 \pm 6.10(109)$ & $30.9 \pm 15.9(150)$ & $52.8 \pm 34.2(362)$ & $33.4 \pm 26.7(731)$ \\
\hline$\sigma_{a p}\left(\mathrm{Mm}^{-1}\right)$ & $0.51 \pm 0.17(32)$ & $0.54 \pm 0.22(26)$ & $1.26 \pm 1.20(80)$ & $1.83 \pm 1.51(324)$ & $1.6 \pm 1.5(462)$ \\
\hline \multicolumn{6}{|l|}{ b. columnar } \\
\hline$\delta_{a e}$ & $0.09 \pm 0.03(41)$ & $0.13 \pm 0.031(39)$ & $0.21 \pm 0.061(60)$ & $0.45 \pm 0.17(179)$ & $0.28 \pm 0.15$ (319) \\
\hline \multicolumn{6}{|l|}{ 2. Intensive } \\
\hline$\delta_{a e} F F$ & $0.21 \pm 0.091(41)$ & $0.19 \pm 0.11(39)$ & $0.35 \pm 0.16(60)$ & $0.26 \pm 0.15(179)$ & $0.27 \pm 0.16(319)$ \\
\hline \multicolumn{6}{|l|}{ b. surface } \\
\hline$R_{s p}$ & $0.15 \pm 0.04(110)$ & $0.14 \pm 0.05(101)$ & $0.26 \pm 0.11(150)$ & $0.23 \pm 0.09(358)$ & $0.22 \pm 0.10(719)$ \\
\hline $\boldsymbol{R}_{a p}$ & $0.62 \pm 0.14(51)$ & $0.63 \pm 0.17(23)$ & $0.65 \pm 0.11(64)$ & $0.39 \pm 0.18(209)$ & $0.48 \pm 0.24(347)$ \\
\hline$\stackrel{\circ}{a}$ & $0.33 \pm 0.16(110)$ & $0.33 \pm 0.18(101)$ & $0.63 \pm 0.49(150)$ & $0.44 \pm 0.34(358)$ & $0.46 \pm 0.36(719)$ \\
\hline$\omega_{0}$ & $0.99 \pm 0.01(76)$ & $0.99 \pm 0.01(70)$ & $0.96 \pm 0.03(82)$ & $0.96 \pm 0.02(330)$ & $0.96 \pm 0.03(558)$ \\
\hline$\Delta R F / \delta_{a e}\left(\mathrm{Wm}^{-2}\right)$ & $-28 \pm 0.061(76)$ & $-27 \pm 0.75(70)$ & $-27 \pm 1.1(82)$ & $-26 \pm 0.87(331)$ & $-26.7 \pm 1.25(559)$ \\
\hline
\end{tabular}


Atmos. Chem. Phys. Discuss., https://doi.org/10.5194/acp-2017-703

Manuscript under review for journal Atmos. Chem. Phys.

Discussion started: 18 September 2017

(c) Author(s) 2017. CC BY 4.0 License.
Atmospheric

Chemistry

and Physics

Discussions

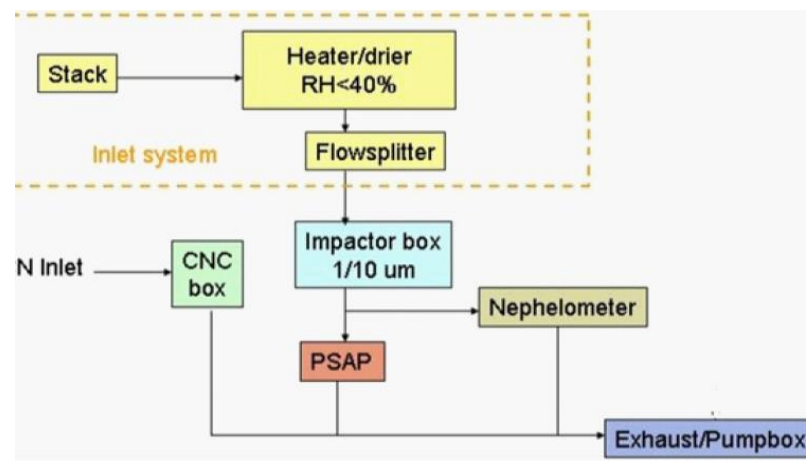

Figure 1. Diagram of aerosol monitoring system at CPR.
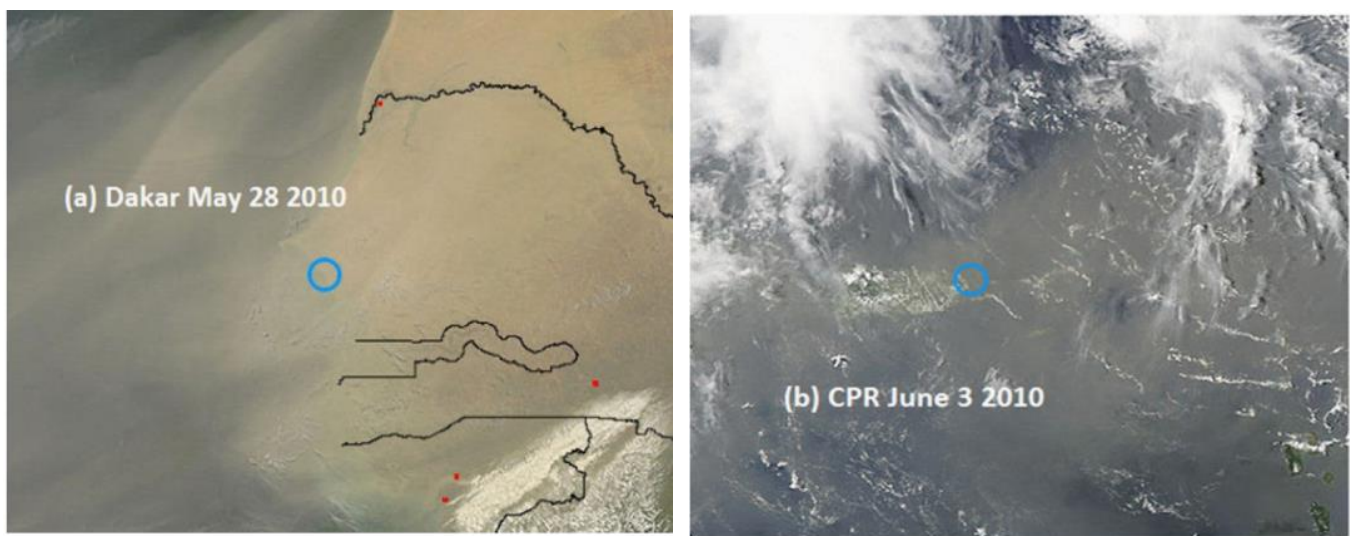

5 Figure 2. (a) African dust cloud over Dakar, Africa. (b) African dust cloud over Puerto Rico, the Caribbean and Atlantic. (Source: https://aeronet.gsfc.nasa.gov/cgi-bin/bamgomas_interactive)

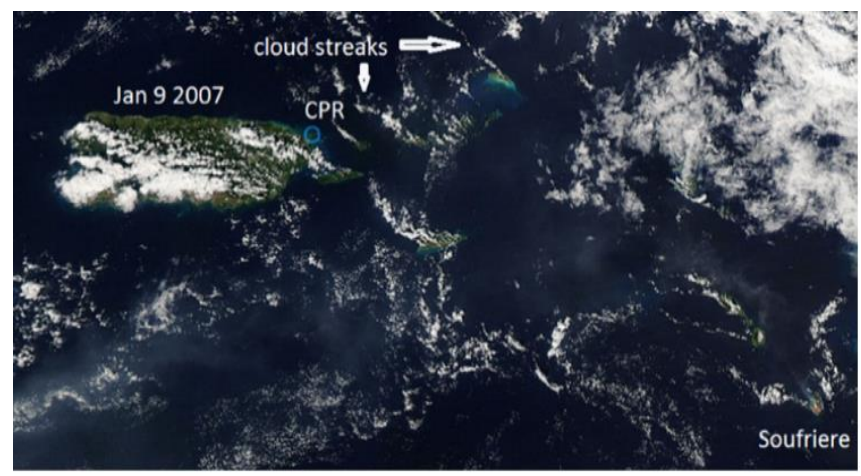

Figure 3. Volcanic ash reaching Puerto Rico under a southeast flow.

10 (Source: https://aeronet.gsfc.nasa.gov/cgi-bin/bamgomas_interactive) 
Atmos. Chem. Phys. Discuss., https://doi.org/10.5194/acp-2017-703

Manuscript under review for journal Atmos. Chem. Phys.

Discussion started: 18 September 2017

(c) Author(s) 2017. CC BY 4.0 License.

\section{(c) (1)}

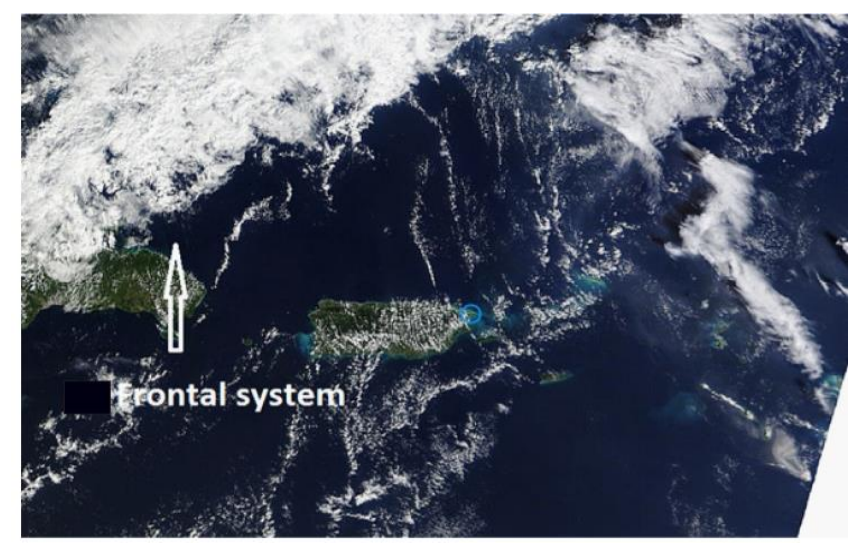

Figure 4. Volcanic ash plume northeast of Puerto Rico.

(Source: https://aeronet.gsfc.nasa.gov/cgi-bin/bamgomas_interactive)
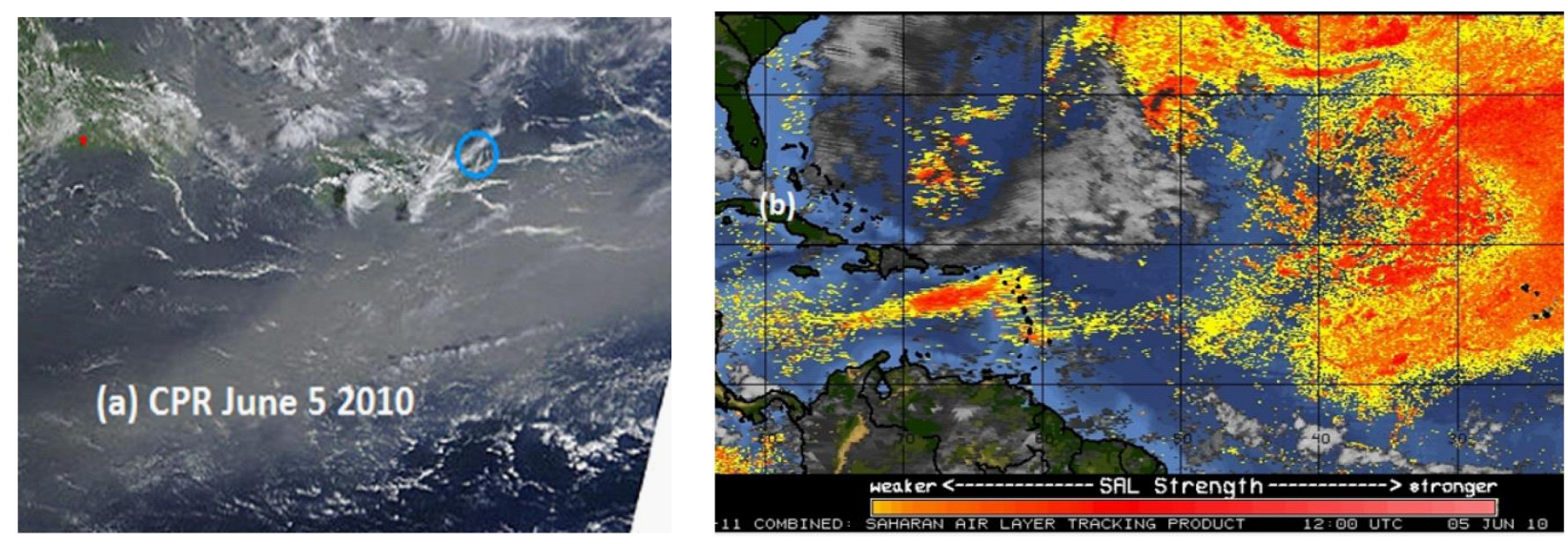

Figure 5. (a) Dust cloud over Puerto Rico and adjacent waters June 5, 2010. (b) SAL image June 5, 2010.

(Source: (a) https://aeronet.gsfc.nasa.gov/cgi-bin/bamgomas_interactive, (b) http://tropic.ssec.wisc.edu/archive/). 
Atmos. Chem. Phys. Discuss., https://doi.org/10.5194/acp-2017-703

Manuscript under review for journal Atmos. Chem. Phys.

Discussion started: 18 September 2017

(c) Author(s) 2017. CC BY 4.0 License.

(c) (1)

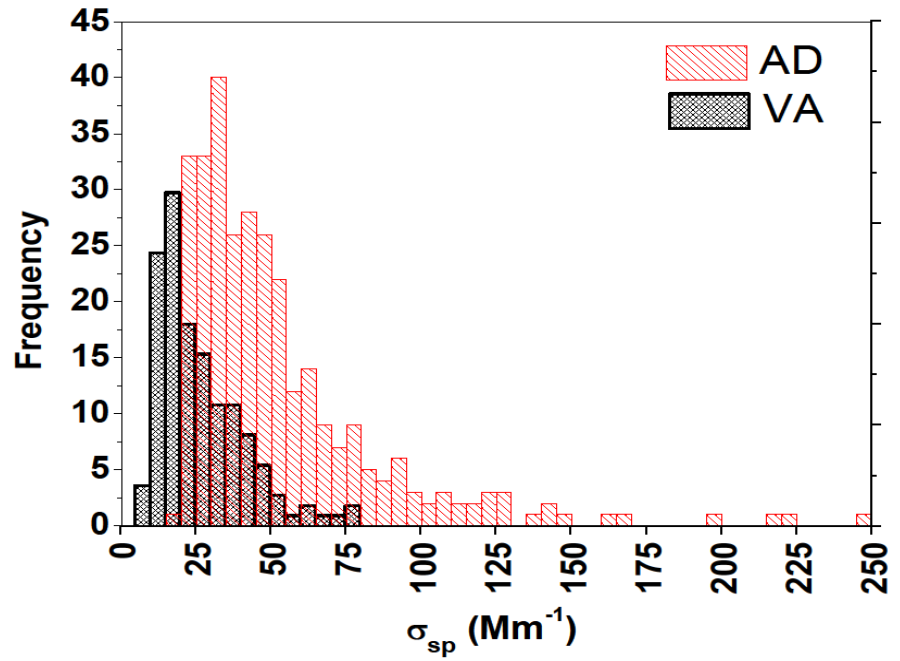

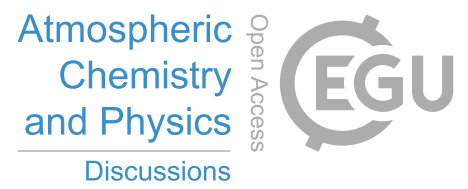

Figure 6. Frequency distribution of the scattering coefficient $\sigma_{s p}$, for $\mathrm{AD}$ and VA. 
Atmos. Chem. Phys. Discuss., https://doi.org/10.5194/acp-2017-703

Manuscript under review for journal Atmos. Chem. Phys.

Discussion started: 18 September 2017

(c) Author(s) 2017. CC BY 4.0 License.
Atmospheric

Chemistry

and Physics

Discussions
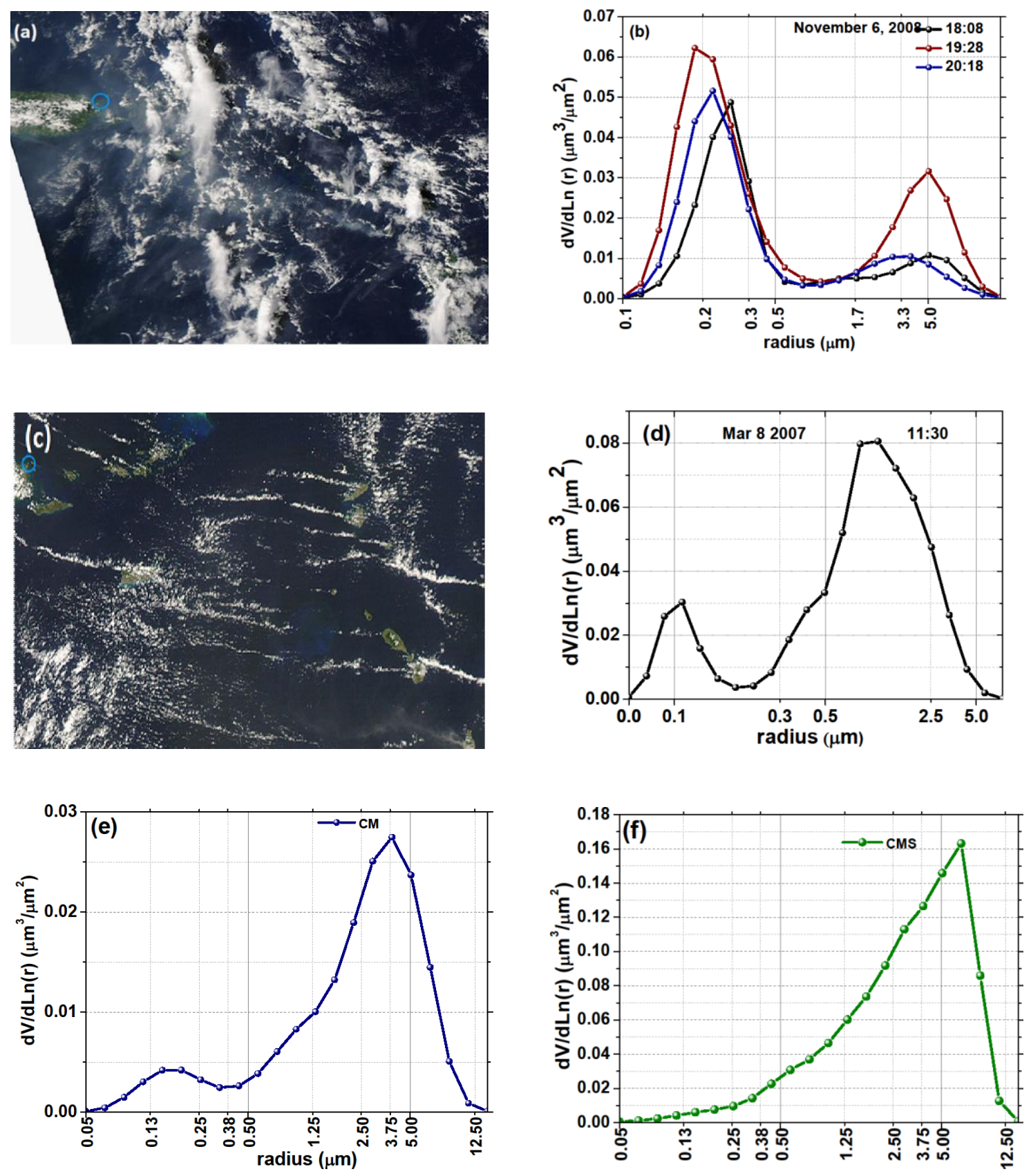

Figure 7. (a) Volcanic ash event over CPR in November 6, 2008. (b) Volume size distribution at various times in November 6, 2008. (c) Volcanic ash event on March 8, 2007. (d) Volume size distribution corresponding to the event on March 8, 2007. (e) Mean volume size distribution for the CM air mass. (f) Mean volume size distribution for the CMS air mass.

(Source: Figures 7 (a) and (c) https://aeronet.gsfc.nasa.gov/cgi-bin/bamgomas interactive) 
Atmos. Chem. Phys. Discuss., https://doi.org/10.5194/acp-2017-703

Manuscript under review for journal Atmos. Chem. Phys.

Discussion started: 18 September 2017

(c) Author(s) 2017. CC BY 4.0 License.

\section{(c) (i)}

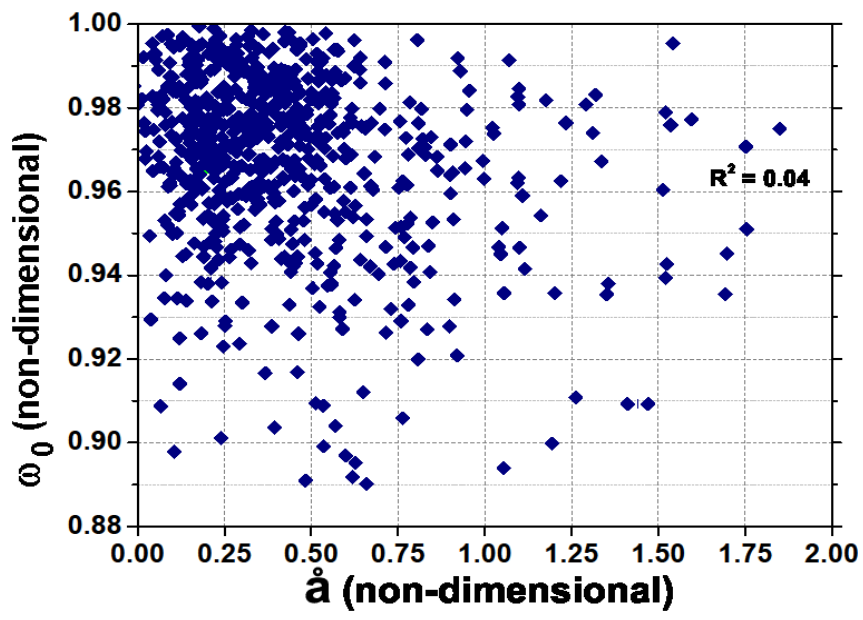

Atmospheric

Chemistry

and Physics

Discussions

Figure 8. Variation of the single scattering albedo with the Ångström exponent (å).
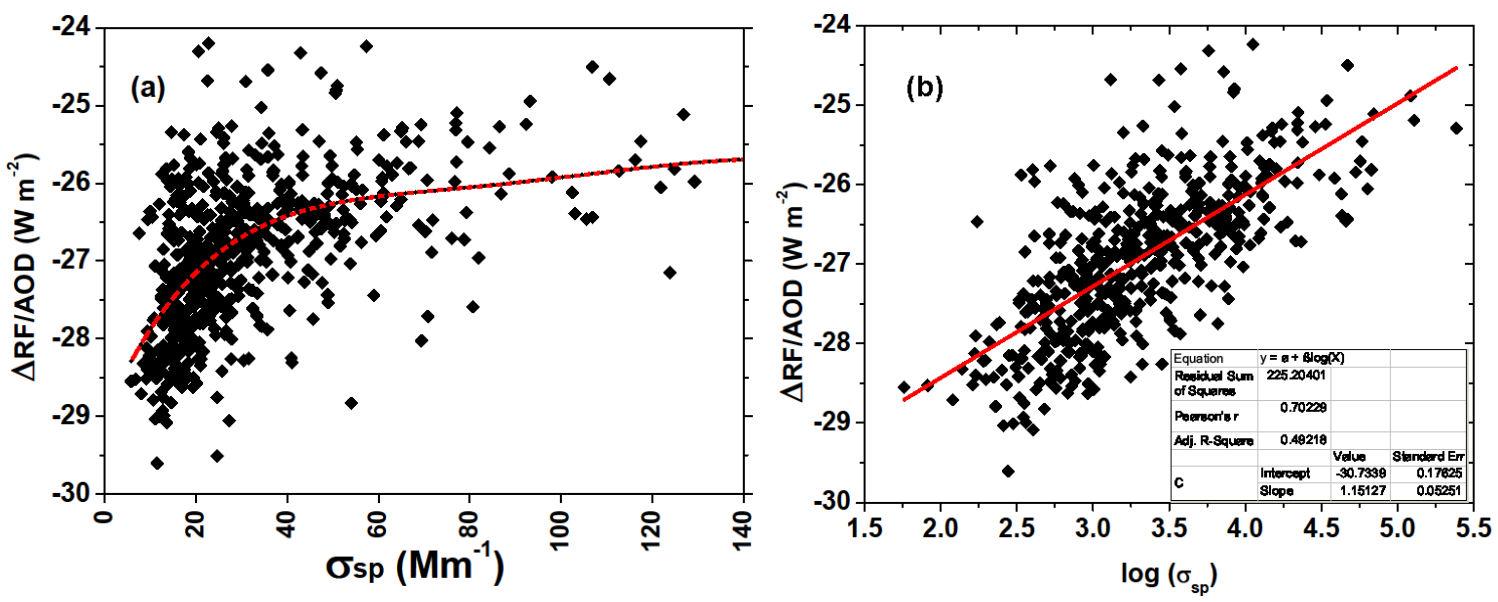

5 Figure 9. (a) Variability of the radiative forcing efficiency $\Delta \mathrm{RF} / \delta_{\mathrm{ae}}$ with the scattering coefficient $\sigma_{\mathrm{sp}}$. (b) Variability of the radiative forcing efficiency $\Delta \mathrm{RF} / \delta_{\mathrm{ae}}$ with the natural logarithm of $\sigma_{\mathrm{sp}}$. 
Atmos. Chem. Phys. Discuss., https://doi.org/10.5194/acp-2017-703

Manuscript under review for journal Atmos. Chem. Phys.

Discussion started: 18 September 2017

(c) Author(s) 2017. CC BY 4.0 License.

\section{(c) (i)}

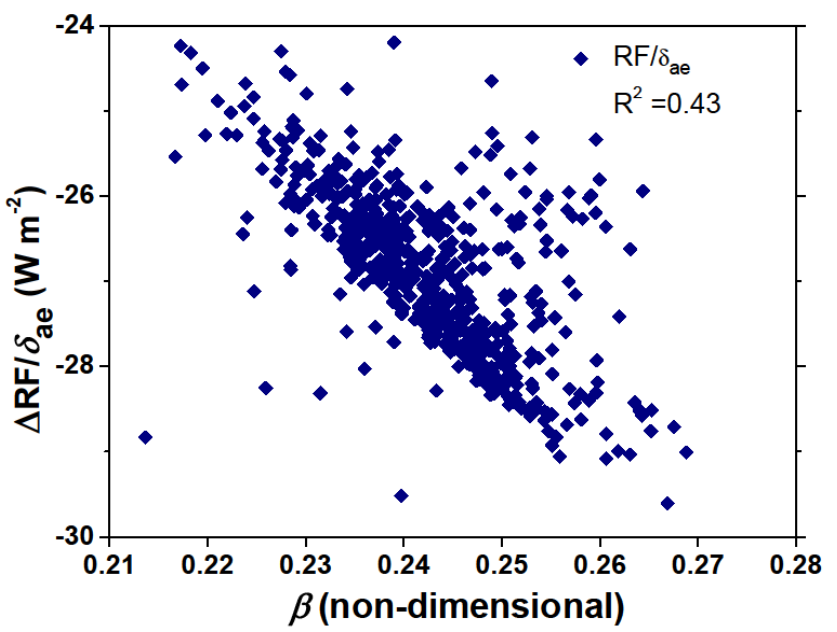

Figure 10 . Variability of $\Delta \mathrm{RF} / \delta_{\mathrm{ae}}$ with the size dependent $\beta$.

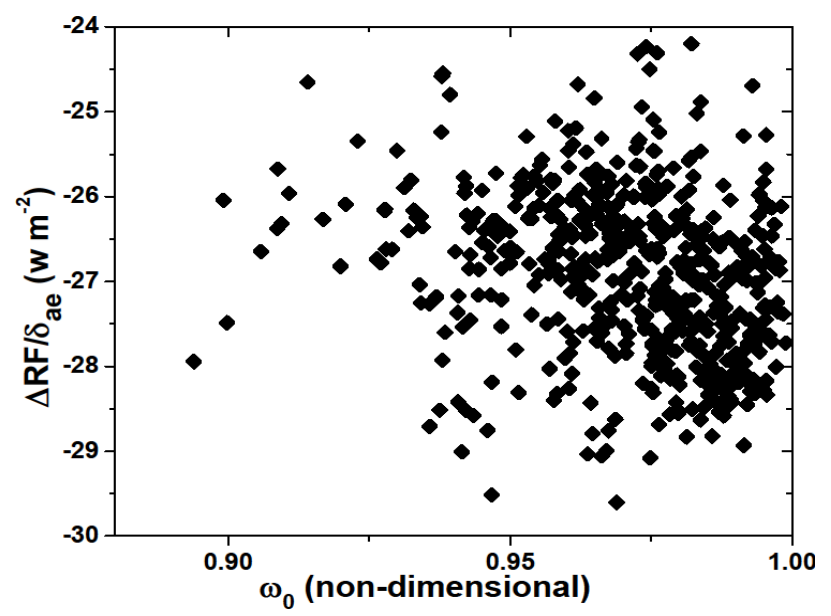

5 Figure 11. Variability of the Radiative forcing efficiency $\Delta R F / \delta_{a e}$ as a function of the single scattering albedo $\left(\omega_{0}\right)$.
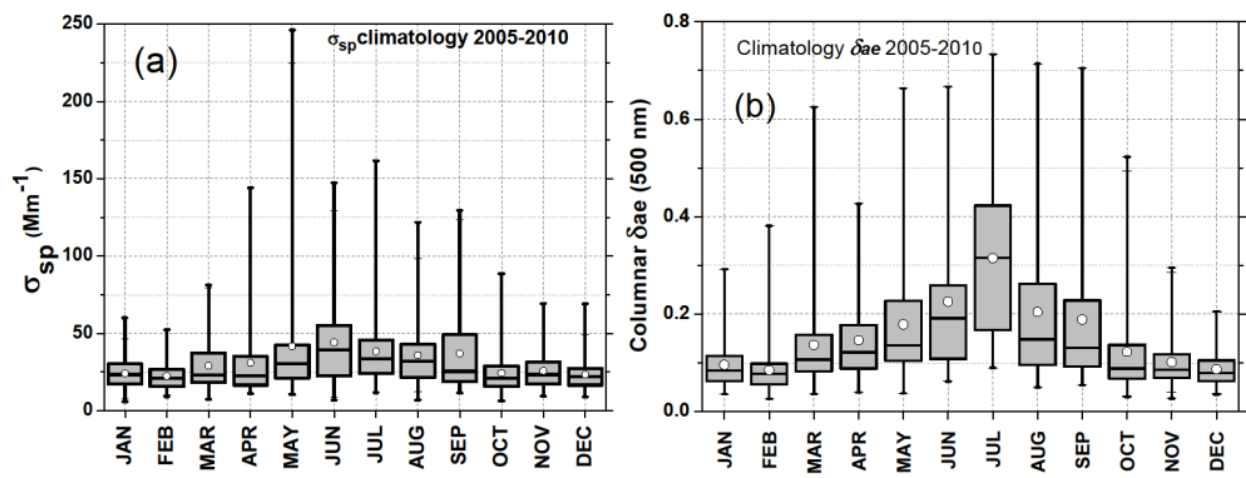
Atmos. Chem. Phys. Discuss., https://doi.org/10.5194/acp-2017-703

Manuscript under review for journal Atmos. Chem. Phys.

Discussion started: 18 September 2017

(C) Author(s) 2017. CC BY 4.0 License.
Atmospheric 을

Chemistry

and Physics

Discussions

Figure 12. (a) Monthly variation of the scattering coefficient $\left(\sigma_{\mathrm{sp}}\right)$ and (b) monthly variation the columnar optical depth $\left(\delta_{\mathrm{ae}}\right)$ using daily averages.

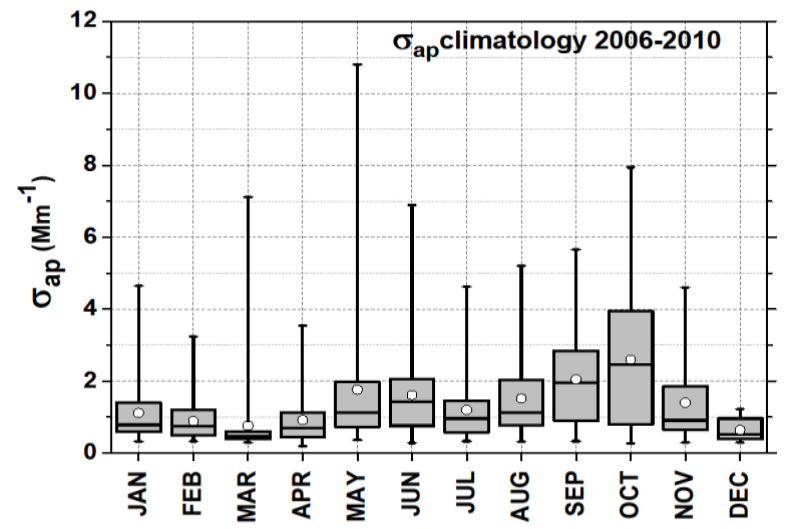

Figure 13 . Monthly variation of $\sigma_{\text {ap }}$ using daily averages.
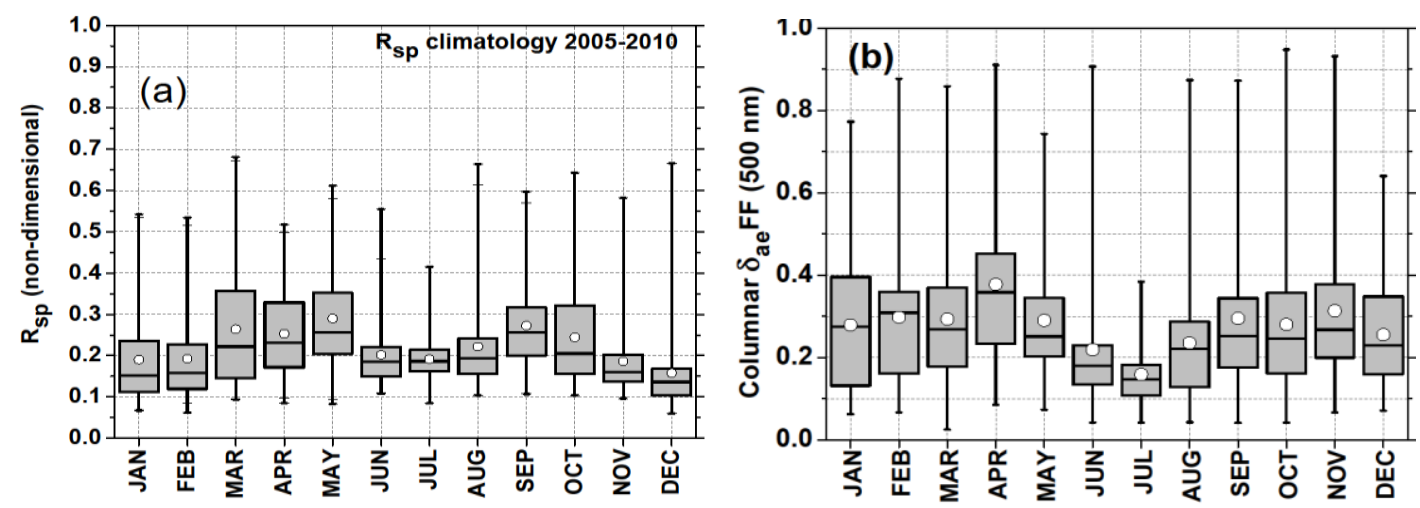

Figure 14. (a) Monthly climatology of $\mathrm{R}_{\mathrm{sp}}$ and (b) Columnar aerosol optical depth fine fraction $\delta_{\mathrm{ae}} \mathrm{FF}$, using daily averages.

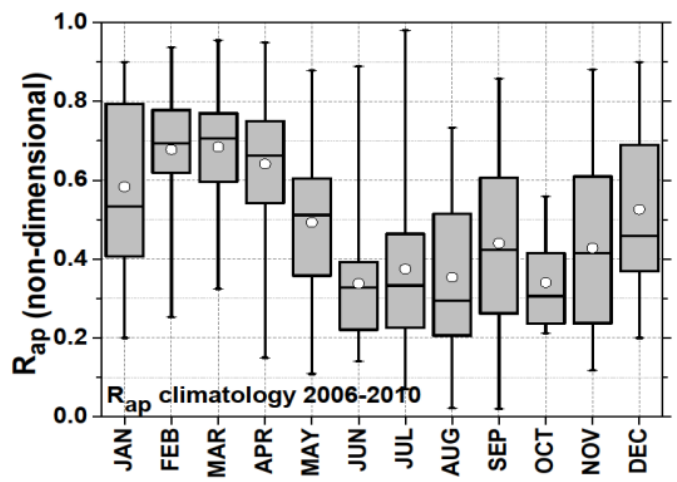


Atmos. Chem. Phys. Discuss., https://doi.org/10.5194/acp-2017-703

Manuscript under review for journal Atmos. Chem. Phys.

Discussion started: 18 September 2017

(c) Author(s) 2017. CC BY 4.0 License.

\section{(c) (1)}

Figure 15. Monthly climatology of $\mathrm{R}_{\mathrm{ap}}$ using daily averages.
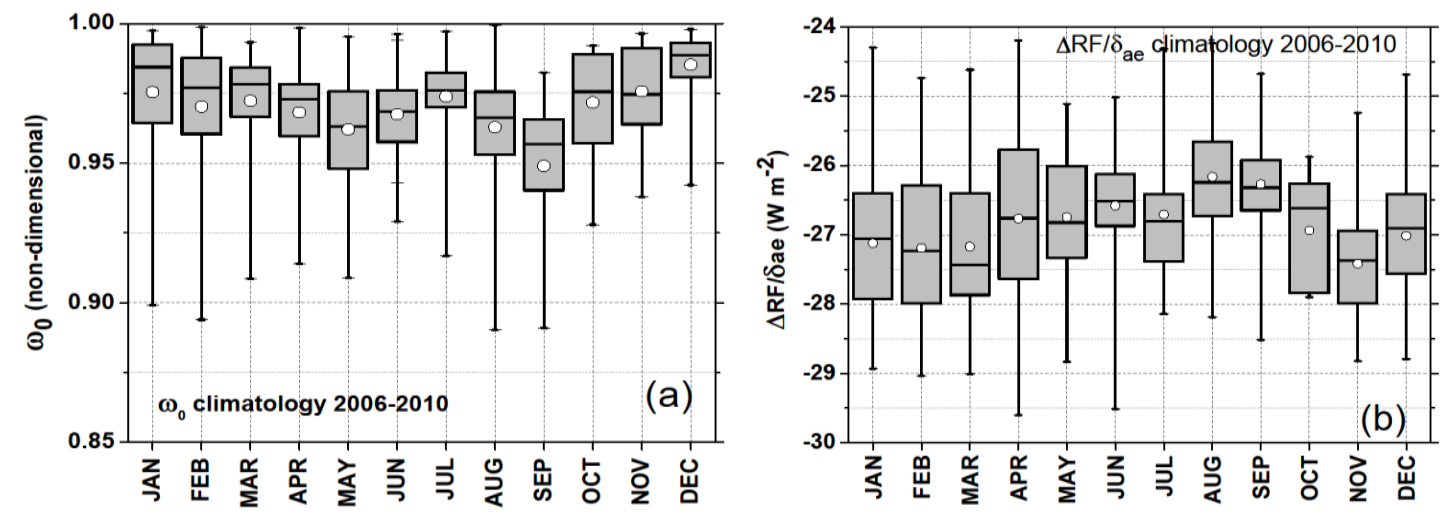

Figure 16. Climatology of (a) $\omega_{0}$ and (b) $\Delta \mathrm{RF} / \delta_{\text {ae }}$ using daily averages. 